\title{
Economic Analysis of
}

Proposed Voluntary Energy

Conservation Standard for

New Residential Buildings
S. J. Marsh
J. W. Callaway
J. M. Roop
Z. T. Taylor

June 1989

Prepared for the U.S. Department of Energy under Contract DE-AC06-76RLO 1830

Pacific Northwest Laboratory

Operated for the U.S. Department of Energy

by Battelle Memorial Institute 


\title{
DISCLAIMER
}

This program was prepared as an account of work sponsored by an agency of the United States Government. Neither the United States Government nor any agency thereof, nor Battelle Memorial Institute, nor any of their employees, makes any warranty, express or implied, or assumes any legal liability or responsibility for the accuracy, completeness, or usefulness of any information, apparatus, product, or process disclosed, or represents that its use would not infringe privately owned rights. Reference herein to any specific commerical product, process, or service by trade name, trademark, manufacturer, or otherwise, does not necessarily constitute or imply its endorsement, recommendation, or favoring by the United States Government or any agency thereof, or Battelle Memorial Institute. The views and opinions of authors expressed herein do not necessarily state or reflect those of the United States Government or any agency thereof.

\author{
PACIFIC NORTHWEST LABORATORY \\ operated by \\ BATTELLE MEMORIAL INSTITUTE \\ for the \\ UNITED STATES DEPARTMENT OF ENERGY \\ under Contract DE-AC06-76RLO 1830
}

\author{
Printed in the United States of America \\ Available from \\ National Technical Information Service \\ United States Department of Commerce \\ 5285 Port Royal Road \\ Springfield, Virginia 22161 \\ NTIS Price Codes \\ Microfiche A01 \\ Printed Copy
}

$\begin{array}{lc}\text { Pages } & \begin{array}{c}\text { Price } \\ \text { Codes } \\ 001-025\end{array} \\ 026-050 & \text { A02 } \\ 051-075 & \text { A03 } \\ 076-100 & \text { A04 } \\ 101-125 & \text { A05 } \\ 126-150 & \text { A06 } \\ 151-175 & \text { A07 } \\ 176-200 & \text { A0B } \\ 201-225 & \text { A09 } \\ 226-250 & \text { A10 } \\ 251-275 & \text { A11 } \\ 276-300 & \text { A12 } \\ & \text { A13 }\end{array}$


PNL -6673

UC-95d

ECONOMIC ANALYSIS OF

PROPOSED VOLUNTARY ENERGY

CONSERVATION STANDARD FOR

NEW RESIDENTIAL BUILDINGS

S. J. Marsh

J. M. Roop

J. W. Callaway

Z. T. Taylor

June 1989

Prepared for

the U.S. Department of Energy

under Contract DE-ACO6-76RLO 1830

Pacific Northwest Laboratory

Richland, Washington 99352 


\section{SUMMARY}

The economic analysis of the proposed voluntary residential energy (VOLRES) standard for new residential buildings concludes that there are no significant adverse effects from adopting the vOLRES standard. When compared with current practice, the proposed standard will result in a positive net flow of benefits from energy savings that more than offsets higher capital construction and other costs. By calculating the life-cycle cost of new construction as currently practiced and the life-cycle cost of construction that would be required by the standard, the regional and national net benefits of the standard over a 15-year period have been estimated.

The analysis leads to the following major conclusions, expressed in constant 1986 dollars:

- The national net effect of the standard, assuming its immediate and full penetration, ranges from nearly $\$ 930$ million in net benefits for 1988 construction to $\$ 1035$ mi11ion for 1992 construction.

- This net effect is based on the net present value of energy savings and capital costs over the 15-year period. For 1992 construction, the year with the largest net effect, the capital costs of construction to comply with the standard are $\$ 1.2$ billion. The energy savings accrued over the 15-year period for 1992 construction are nearly $\$ 2.2$ billion. The difference represents a net benefit of $\$ 1.0$ bition.

- Because the standard is voluntary, there is some question about how rapidly it will be adopted. To examine the impact of this, the net benefits were also calculated assuming a ramped penetration of the standard over five years (20 percent per year). The national net effect of the standard ranges from nearly $\$ 186$ million in net benefit for construction in 1988 to $\$ 1035$ million for construction in 1992. (Full penetration of the standard occurs in 1992.)

The standard creates a net benefit for all regions. Assuming full penetration of the standard, the Northeast receives the greatest benefit until 1993 when the net benefits in the South overtake those of the 
net benefit to the Northeast increases from $\$ 336$ million for 1988 constructicn to $\$ 384$ million for 1992 construction, after which the net benefits drop steadily until the construction period from 2001 to 2005, when they reach $\$ 220 \mathrm{milli}$ ion. In magnitude, the West region's net benefit is the lowest of all regional benefits from 1988 to 2005 . Changes in the relative share of net costs and benefits are attributable to changes in the distribution of regional housing forecasts.

The total impact of the standard, as measured in the gross value of industry output and employment, was estimated using the U.S. input-output table (OOC 1984). For the purposes of this analysis, the effects of the enerjy savings have been assumed to occur in the year of construction when, in reality, the energy savings are spread over fifteen years. In 1992, the construction year with the greatest indirect impacts, the combined effect of output changes results in a net loss of approximately $\$ 2.5$ billion in output. This decrease in output is the difference between a $\$ 2.2$ billion increase in output resulting from increased capital expenditures for construction and the $\$ 4.7$ billion decrease in output resulting from lower energy expenditures. Even when all of the output effects of changes in energy costs over fifteen years are assume'd to occur in the initial year of construction, the output change represents only 0.05 percent of the total U.S. Gross National Product.

The greatest total effect on employment is the net loss of 10,800 jobs associated with 1991 construction. While neariy 31,800 jobs are gained as a result of increased construction, over 42,600 are lost as a result of decreasej energy expenditures. This estimate of employment effects, probabiy an overestimate since it does not take into account alternative patterns of consumption, is less than 0.01 percent of total U.S. employment.

These findings are predicated on assumptions about current energy prices. social discount rates, and the distribution of new residential construction, fuel/equipment and foundation type preferences. A sensitivity analysis was performed on fuel prices, and the ramifications of changes in other economic variables were assessed.

The sensitivity analysis reveals that ARES is sensitive to fuel prices. When fuel prices are increased by 50 percent, the net benefit of the proposed 
standard increases substantially. The national net benefit reaches its highest level for construction in 1992 with a net benefit of $\$ 2.2$ billion. On the other hand, when fuel prices decrease, the proposed standard could result in less energy-efficient construction than is currently required by state codes.

The calculation of the net benefit of the proposed standard under alternative time horizons, reveals that under a seven-year time horizon, the proposed standard would result in a net cost to society in all construction years. Under a 30-year time horizon, the national net benefit is substantially higher than the net benefit over the 15-year time horizon.

The homeowner's perspective is also assessed as part of the sensitivity analysis. For all years of construction, the proposed standard would generate a net benefit for homeowners. 



\section{ACKNOWLEDGMENTS}

We would like to express gratitude for help and guidance in the completion of this report. This report was authored by Sarah J. Marsh and Joseph M. Roop. Allen Lee, Ray Reilly, and Michael R. Brambley served as project managers, with Jenifer $W$. Callaway providing leadership for the component tasks that comprise the Regulatory Analysis. The characterization of the base case was also done under the direction of Jenifer W. Callaway. John Rivera wrote the Notice of Proposed Regulation (NOPR). Z. Todd Taylor managed the development and provided the technical description of the standard. Technical recommendations were provided by the American Society of Heating, Refrigerating, and Air-Conditioning Engineers Special Project 53 Committee. Steven Walder acted as the contract monitor for the Department of Energy. At Pacific Northwest Laboratory, we owe special thanks to Cynthia Turney and other capable staff who helped organize and construct the data for this report. 



\section{CONTENTS}

SUMMARY

ACKNOWLEDGMENTS

vi i

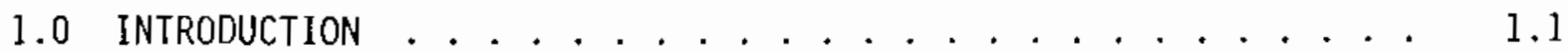

1.1 BACKGROUND . . . . . . . . . . . . . . . . . 1.1

1.1.1 Legislative Background .............. 1.1

1.1.2 Sumnary of the Original Proposal . . . . . . 1.2

1.1.3 The Present Proposal . . . . . . . . . . 1.3

1.2 REPORT STRUCTURE . . . . . . . . . . . . . . . . 1.4

2.0 DESCRIPTION OF THE PROPOSED STANDARD AND ALTERNATIVES . . . . . 2.1

2.1 THE PROPOSED STANDARD . . . . . . . . . . . . . . . 2.1

2.1.1 The Automated Residential Energy Standard Computer Software.............. . . . 2.3

2.1.2 The Energy Data Base . . . . . . . . . . . 2.3

2.1.3 The Cost Data Base . . . . . . . . . . . 2.4

2.1.4 The Life-Cycie Cost Optimization . . . . . . . . 2.5

2.1.5 Prescriptive Package Compliance Alternative . . . . 2.6

2.1.6 Point System Compliance Alternative. . . . . . . 2.7

2.1.7 Performance Compliance Alternative . . . . . . . 2.7

2.2 NO-ACTION ALTERNATIVE . . . . . . . . . . . . . . . 2.7

2.2.1 Base Case Energy-Efficiency Requirements . . . . . 2.8

3.0 ECONOMIC IMPACTS OF THE PROPOSED STANDARD . . . . . . . . . . . 3.1

3.1 DIRECT IMPACTS OF PROPOSED STANDARD . . . . . . . . . 3.1

3.1.1 National Impacts . . . . . . . . . . . . . 3.1

3.1.2 Regional Impacts ................ 3.4

3.1.3 Sensitivity Analysis Results . . . . . . . . . 3.4 
3.2 OUTPUT AND EMPLOYMENT IMPACTS . . . . . . . . . 3.12

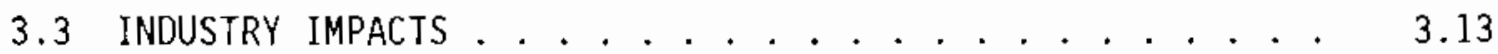

3.3.1 Institutional Impacts ............ 3.16

4.0 METHODOLOGY . . . . . . . . . . . . . . . . . . . . . 4.1

4.1 OVERVIEW OF THE ANALYTICAL PROCESS . . . . . . . . . . 4.1

4.2 BUILDING CONFIGURATION USING ARES . . . . . . . . . 4.3

4.3 CALCULATION OF LIFE-CYCLE COSTS . . . . . . . . 4.5

4.4 AGGREGATION OF DIRECT IMPACTS . . . . . . . . . . . . 4.6

4.5 CALCULATION OF TOTAL IMPACTS . . . . . . . . . . . . . 4.7

4.6 SENSITIVITY ANALYSIS . . . . . . . . . . . . . . . 4.12

4.7 DATA . . . . . . . . . . . . . . . . . . 4.12

APPENDIX A - DESCRIPTION OF HOUSING PROTOTYPES UNDER THE

PROPOSED STANDARD ............... A.1

APPENDIX B - DETAILED DATA AND SAMPLE ARES RUNS . . . . . . . . B. 1

REFERENCES .......................... R.1 


\section{FIGURE}

4.1 Overview of the Analytical Process ........... 4.2

\section{$\underline{\text { TABLES }}$}

3.1 Net Change of Regional and National Life-Cycle Costs, 15-Year Time Horizon, Full Penetration of the Standard . . . 3.2

3.2 Net Change of Regional and National Life-Cycle Costs, 15-Year Time Horizon, Ramped Penetration of the Standard . . . 3.3

3.3 Net Change of Regional and National Life-Cycle Costs, 15-Year Time Horizon, Full Penetration of the Standard, Fue 1 Prices Increased by 50\% . . . . . . . . 3.6

3.4 Net Change of Regional and National Life-Cycle Costs, 7-Year Time Horizon, Full Penetration of the Standard . . . . 3.8

3.5 Net Change of Regional and National Life-Cycle Costs, 30-Year Time Horizon, Fu11 Penetration of the Standard . . . 3.10

3.6 Net Change of Regional and National Life-Cycle Costs, 7-Year Time Horizon, Full Penetration of the Standard, Homeowners' Perspective .............. 3.11

3.7 Total Impacts of the Proposed Standard, Full Penetration . . 3.14

4.1 Economic Parameters Used in the Economic Analysis . . . . . 4.4

4.2 Locations and Census Regions ............. 4.4

4.3 Regional Factors Used in Aggregation Process, Single-Family Housing . . . . . . . . . . . . 4.8

4.4 Regional Factors Used in Aggregation Process, Multi-Family Housing ................ 4.9

4.5 Regional Factors Used in Aggregation Process, Manufactured Housing .................. 


\subsection{INTRODUCTION}

The objective of this document is to present an anatysis of the impacts of the proposed voluntary energy conservation standard for the construction of new residential buildings. This analysis examines the impacts of having the proposed residential standard apply immediately and, alternatively, having the proposed standard phased in over a five-year period. It does not address the question of whether realistically the standard would be adopted by states, nor does it weight the improbable impact of states with higher energy efficiency standards modifying their standard to comply with this voluntary standard.

\subsection{BACKGROUND}

The proposed voluntary standard for new residential buildings has undergone considerable revision since its inception in 1977. This section provides a brief legislative history of the standard and then describes the original and present proposals.

\subsubsection{Legislative Background}

As originally enacted, Title III of the Energy Conservation and Production Act, Pub. L. No. 94-385, 90 Stat. 1144 et seq., required action to develop, promulgate, implement and enforce compliance with performance standards to improve energy efficiency of all new buildings in the nation. The regulatory nature of this action was modified by the Energy Conservation Standards for New Buildings Act of 1976, as amended, (the Act) (42 U.S.C. 6831 et. seq.). Responsibility for this action was transferred to the U.S. Department of Energy (DOE) on August 4, 1977, with the passage of Section 304(a), 42 U.S.C. Sec. 7154, of the Department of Energy Organization Act, Pub. L. No. 95-91.

In November 1979, DOE published proposed performance standards in the Federa1 Register, 44 FR 68120, et seq. The standards, expressed as maximum energy consumption leve's (Btu's per square foot per year), were very controversia], generating over 1800 comments. Many commenters expressed concern that the proposed standards were not technically practicable or economically 
achievable. Furthermore, many commenters stated that the proposed standards placed too great a reliance upon the use of a complex computer program which many commenters said they neither understood nor could afford to use.

Less than a year after the publication of the proposed standard, the Act: was again amended by Section 326 of the Housing and Community Development Ac: of 1980, Pub. L. No. 96-399 (0ctober 8, 1980). This amendment required that DOE promulgate interim standards and extended the promulgation date of the final standard to April 1, 1983. In addition, the Act required that demonstration projects be conducted in at least two geographical areas.

In August 1981, Congress again amended the Act and deferred the appropriation for the program from the 1981 fiscal year to the 1982 fiscal year. Subtitle D of Title 10 of the Omnibus Reconciliation Act of 1981, Pub. L. No. 97-35, amended the Act to create the term "voluntary performance standard," eliminated the provision for a possible statutory sanction for noncom. pliance, and added a provision that, except for federal buildings, "voluntary standards will be developed solely as guidelines to provide technical assistance for the design and construction of energy efficient buildings."

\subsubsection{Summary of the Original Proposal}

The most significant aspect of the proposed Building Energy Performance Standards (BEPS), issued in 1979, was that they were a performance standard that set energy limits for the building as a whole. BEPS attempted to combine energy use of, and permit trade-offs for specific energy-using systems such as heating, cooling or domestic hot water. The proposed standards consisted of three requirements. First, energy budget levels would be set; second, they would be applied to a specific building design to obtain an annual rate of consumption; and third, the estimated general rate of energy consumption would be calculated using a method established by DOE. The whole process required the use of a computer simulation to demonstrate that the designed energy consumption of a new building did not exceed the energy lever specified for a residential building of its type in its applicable climate area. The BEPS was based on life-cycle cost analyses and defined different residential building types (multi-family high-rise, multi-family low-rise, 
single-family attached and single-family detached) as well as a procedure to select an appropriate climate zone from 78 Standard Metropolitan Statistical Areas (SMSA).

DOE recognized that many aids, such as model codes or building energy simulation software, would be needed to reduce compliance complexities. It also acknowledged that tools needed to be in formats familiar to members of the building industry. These compliance assistance tools were in the process of being developed by DOE when the implementation sections of the statutes were repealed by the Omnibus Reconciliation Act. The entire package of compliance assistance tools was never completed, but a slide rule and A Guide to Designing and Constructing Energy Efficient Homes was issued in 1983.

\subsubsection{The Present Proposal}

In response to the revised legislation and to comments made on the proposed BEPS, DOE is now reproposing performance standards for the private sector. Because of the difference in the economics and process of federal design and construction of residential buildings, DOE is issuing separate standards for the federal and private sector. Mandatory standards for new federal residential building had been developed previously and are soon to be issued by DOE.

The proposed voluntary standard is for private sector construction and for federally-subsidized private housing only. As such, DOE would not be regulating private sector construction, but rather issuing guidelines to provide technical assistance for the designs and construction of energyefficient buildings. The proposal represents a significant federal effort to help the private sector develop energy conservation standards without regulatory intrusion. To develop the proposed standard DOE has worked closely with a special projects committee from the American Society of Heating, Refrigerating and Air-Conditioning Engineers, Inc. (ASHRAE). The research project jointly undertaken by DOE and ASHRAE culminated in the proposed interim voluntary standard.

The proposed standard is presented in the format commonly used by the private sector standards-setting organization rather than as a federal regulation. For example, the proposal contains extensive explanatory material 
not normally inciuded in federal standards. By submitting the proposed interim standards in a form that is likely to be better understood and more readily used in the private sector, DOE hopes to improve the standard's transferability.

As defined by the Act, the proposed standard serves as a guideline for the design of new residences; it does not apply to the operation, maintenance or energy consumption of a building once it is built. The proposed standard operates by setting an energy cost goal for a building (i.e., a quantified target for energy cost at the design stage) and a method to calculate whether the design meets that goal. Through the use of the software ARES (Automatec Residential Energy Standard) which supports the proposed standard, users car also create "packages" of energy conservation components that meet the enercy consumption goal.

\subsection{REPORT STRUCTURE}

Section 2.0 of this report is a description of the proposed standard and alternatives considered. In addition to the proposed standard, the major a) ternative is a set of state-mandated standards that reflect current practice. Both the proposed standard and the alternative are evaluated under assumptions about the economic parameters.

Section 3.0 of this report first examines the economic impact of the proposed standard. The analysis examines the consequence of reconfiguring three building prototypes to meet the proposed standard; each building was analyzed with four alternative foundation types, in ten geographical locations subject to alternative fuel/equipment choices. The building configura-

tions are generated using the ARES software, which selects conservation measures so as to minimize life-cycle costs to the consumer. In the economic analysis, the 1 ife-cycle costs are evaluated from society's perspective rather than from the consumer's perspective. The sensitivity of these results is also assessed.

The remainder of Section 3.0 then explores the potential impacts on a variety of different agents--sectors, industries and smali businesses-in an effort to determine who might be most directly affected by the adoption of 
the proposed standard. The sectors and industries are identified by an examination of these changes to the national economy using an input-output table.

Section 4.0 outlines the methodology used to perform the economic analysis. In this section, the method for calculating the costs and benefits of the proposed standard and data is described in detail. 



\subsection{DESCRIPTION DF THE PROPOSED STANDARD AND ALTERNATIVES}

This section provides information on the proposed voluntary residential energy (VOLRES) standard and the no-action alternative considered in this assessment. Although the development of the proposed standard was mandated by legislation, adoption of the standard by the private sector is voluntary.

Therefore, neither the DOE nor any branch of the federal government would be involved in implementing either the VOLRES standard or the no-action alternative, which is defined as a continuation of current practices and existing energy codes. Adoption of the VOLRES to replace existing energy codes or building practices is a voluntary action on the part of state and local governments or organizations that sponsor model building codes, such as the American Society of Heating, Refrigerating and Air-Conditioning Engineers (ASHRAE) or the Council of American Building officials (CABO).

\subsection{THE PROPOSED STANDARO}

The VOLRES standard has been developed and proposed by DOE in response to legislation requiring the Secretary of Energy to promulgate voluntary energy performance standards that are designed to achieve the maximum practicable improvements in energy efficiency in new residential buildings and to encourage the use of nondepletable energy sources. In response to this legislative mandate, the VOLRES standard sets forth requirements for the design of new residential buildings that would have the most cost-effective combination of energy conservation options integrated into their envelope and equipment components. This standard should lead to residential building designs that produce the maximum practicable energy savings given the criterion of economic cost-effectiveness.

This standard relies on a minimizing life-cycle costs using estimated energy consumption data, construction cost data, climate data, and appropriate consumer financial parameters. The standard is implemented through a computer program documented in Recommendations for Energy Conservation 
Standards for New Residential Buildings, Volume II: Automated Residential Energy Standard = User's Guide. ${ }^{(a)}$

The proposed standard sets forth recommended requirements for the energy construction components that affect the energy use of residential buildings; these components include insulation levels, windows (amount, glazing layers, sash type), infiltration control measures, space conditioning equipment, and domestic hot water conditioning equipment. The standard includes separate requirements for each of three generic housing types: 1) single-family detached housing, 2) multi-family attached housing, and 3) manufactured housing. Within each housing type, separate requirements are set forth for each of five space conditioning equipment combinations: 1) natural gas heat with electric cooling, 2) oil heat with electric cooling, 3) LPG heat with electric cooling, 4) electric resistance heat with electric cooling, and 5) electric heat pump heating and cooling.

The standard requires that residential housing be constructed to minimize the overall costs to the homeowner over the period of ownership. The cash flows included in the assessment of these life-cycle costs are initial construction costs, operation and maintenance costs, energy costs, tax effects, and resale value of the home, all of which are discounted to adjust for inflation and lost opportunity costs. A house complies with this standard if its annual space conditioning energy cost is shown to be less than or equal to an energy cost budget defined as the annual energy cost of a similar house constructed in accordance with the VOLRES Standard, given local construction costs, fuel prices, and economic conditions.

The proposed standard includes minimum requirements for infiltration control measures, but allows stricter measures to be implemented at the user's option if necessary to meet the energy cost budget. The minimum requirements reflect current building practices, such that air exchange rates (assumed to average approximately 0.5 air changes per hour) and indoor air quality are not adversely affected by the standard. The optional tighter measures are specified such that air exchange rates do not fall below 0.35

(a) Draft report, to be published by DOE. 
air changes per hour, the rate below which forced ventilation would be required to maintain acceptable air quality. The tighter measures are never required, but are offered as an option.

\subsubsection{The Automated Residential Energy Standard Computer Software}

Procedures that automate the development of specific criteria for complying with this standard are embodied in the ARES computer program. ARES maintains data bases of estimated residential energy consumption for a variety of locations, construction costs, economic and financial parameters, and typical building characteristics. Using these data, ARES identifies for each locality the combination of energy conservation measures that results in the minimum overall life-cycle costs to the homeowner. The annual energy costs of the optimal house constitute the target energy costs required by this standard. ARES then provides one set of prescriptive requirements (a package) that meets this energy budget, the option to generate additional packages, and a point system designed to allow evaluation of specific building designs against the prescriptive target.

ARES is designed to be used by code officials who are responsible for establishing energy codes in specific jurisdictions. ARES allows the user to modify the various economic, financial, and climatic inputs to tailor the resulting standard to specific localities. It also specifies compliance materials in the form of prescriptive packages and a flexible point system.

\subsubsection{The Energy Data Base}

The ARES energy data base contains annual heating and cooling loads for residential housing built to any common level of thermal integrity in any of 881 locations throughout the United States. The energy data are derived from parametric computer simulations of residential energy performance. The development and formatting of these data are documented in Technical Documentation for a Residential Energy Use Data Base Developed In Support of ASHRAE Special Project 53 . (a)

(a) Draft report to be published by DOE. 


\subsubsection{The Cost Data Base}

ARES' cost data base contains 1986 construction costs for all common ceiling insulation levels, wall insulation levels, crawlspace insulation levels, basement insulation levels, window types, and HVAC equipment. Cost data are included for the following 12 regions of the United States:

\begin{tabular}{ll}
\multicolumn{1}{c}{ Region } & \multicolumn{1}{c}{ States in Region } \\
National Average & All \\
New England & $\begin{array}{l}\text { Connecticut, Massachusetts, Maine, } \\
\text { New Hampshire, Rhode Island, Vermont }\end{array}$ \\
Mid-Atlantic & $\begin{array}{l}\text { District of Columbia, Delaware, Maryland, } \\
\text { New Jersey, New York, Pennsylvania }\end{array}$ \\
Mid-South & $\begin{array}{l}\text { Georgia, North Carolina, South Carolina, } \\
\text { Virginia, West Virginia }\end{array}$ \\
Florida & Florida \\
South Central & $\begin{array}{l}\text { Alabama, Arkansas, Kentucky, Louisiana, } \\
\text { Mississippi, Oklahoma, Tennessee, Texas }\end{array}$ \\
Central & Iowa, Kansas, Missouri, Nebraska \\
North Central & Illinois, Indiana, Michigan, Minnesota, North \\
Dakota, Ohio, South Dakota, Wisconsin & Colorado, Nevada, Utah, Wyoming \\
Mountain & Arizona, New Mexico \\
Southwest & Alaska, California, Hawai \\
Pacific Southwest & Idaho, Montana, Oregon, Washington \\
Pacific Northwest & jurisdictions may choose the most appropriate
\end{tabular}




\subsubsection{The Life-Cycle cost Optimization}

The life-cycle cost calculations required by the proposed standard reflect the value of energy conservation measures to a typical homeowner. The life-cycle cost is defined as the sum of the net present values of the following cash flows:

- down payment on loan

- loan fees and other closing costs of loan

- up-front interest charges (points) on loan

- tax deductions on points

- mortgage payments over the analysis period of analysis

- tax deductions on mortgage interest over the analysis period

- space conditioning energy costs over the analysis period

- nonfuel operation and maintenance costs over the analysis period

- resale value of ECMs at the end of the analysis period.

A seven-year period of analysis is used to reflect the median turnover period of home ownership and mortgages. All cash flows are discounted at a user-modifiable alternative investment rate. Mortgage payments and interest payments are based on common financial calculations and current economic parameters that must be supplied by the user. The resale value of the energy conservation measure is assumed to be identical to its initial cost in current dollars at the end of the period of analysis. Thus the energy conservation measures real value is assumed to decline at the rate of inflation.

ARES identifies the minimum life-cycle cost house via an exhaustive search of all combinations of insulation levels, equipment efficiencies, and window types available in the cost data base. In concept, the energy and construction costs of houses built to every unique combination of conservation options are calculated and compared. The combination with the lowest overall life-cycle cost is used as the basis for the energy cost budget. However, there are several constraints applied during the optimization. First, the optimization assumes that the window area of the house is equaliy distributed on the four cardinal orientations. Though this seldom matches the construction of a particular house, it represents the average condition of large numbers of residences. Second, the optimat levels of ceiling 
insulation, wall insulation, windows, and equipment efficiencies are forced to be the same regardless of the foundation type. This is accomplished by identifying a prevalent foundation type for each location, and optimizing a prototypical house with that foundation. Once the upper envelope conservation levels are established, the insulation levels for each additional foundation type are optimized assuming the same upper envelope is installed. Thus, each foundation type results in a unique energy cost budget.

\subsubsection{Prescriptive Package Compliance Alternative}

ARES provides prescriptive packages of options that will meet the energy cost budget associated with the optimal combination of components identified by the 1ife-cycle cost optimization. One prescriptive package is created for each of the five fuel/equipment combinations. However, because of a constraint applied in the program, each prescriptive package differs from the original optimal combination of options (that produced the energy budget). The prescriptive packages assume that windows are equal1y distributed on the east and west faces of the house, rather than on all four faces as is done in the original optimization. This constrained configuration is intended to approximate the worst possible orientation scenario, so that virtuaily any house, regardless of its window placement, would have energy performance at least as good. The purpose is to minimize the possibility that a house allowable under the prescriptive compliance path would not be allowable under the points compliance path (described below). Given this constraint, the ARES prescriptive package identifies the combination of options that meets the energy cost budget with the minimum construction cost.

In addition to the five standard prescriptive packages, the user (state or local governments or building code officials) may develop additional packages to satisfy local preferences. This is accomplished by applying specific constraints, such as a fixed wall insulation level, or windowto-floor area ratio, then allowing ARES to identify the other components of the house that result in acceptable energy use at a minimum construction cost. This facility allows code officials to create simple compliance approaches for technologies and preferences common to their localities. 


\subsubsection{Point System Compliance Alternative}

The point system printed by ARES is designed to allow builders to deviate from the prescriptive packages identified by the cost optimization, while maintaining thermal integrity. Various levels of conservation options are assigned "points," which are tabulated in the compliance materials printed by the program. The points are directly proportional to the annual energy costs of the home, enabling builders to evaluate the energy cost impacts of various construction options. Options that may be evaluated by the point system include various insulation levels, equipment efficiencies, and various window parameters including number of glazings, solar transmittance, and orientation.

\subsubsection{Performance Compliance Alternative}

The proposed standard allows for the construction of any house that has annual energy costs less than or equal to those of the optimal house. To accommodate new and innovative technologies, the standard provides the option of evaluating the energy performance of a design against that of a similar house that complies with the prescriptive requirements. An energy analysis must be conducted for both the design house and the target house using a calculation technique appropriate for the technologies involved. Typical1y, this requires use of a computer simulation tool.

\subsection{NO-ACTION ALTERNATIVE (CURRENT ENERGY CODES AND ENERGY-RELATED BUILDING PRACTICES)}

As noted above, the proposed standard is a recommended leve 1 of energy efficiency for residential building components, the adoption and implementation of which is voluntary in the private sector. For the purpose of this assessment of potential impacts of the standard's implementation, the no-action alternative is the continued application of the energy standards and codes currently in use by states, local governments and other organizations.

At the present time, 33 states have adopted mandatory energy-efficiency standards for residential buildings. Most other states have adopted mode? energy codes that are enforced at the discretion of local governments. Most 
of these mandatory and model standards are based on several prominent standards that were developed in the late 1970s and early 1980s by such organizations as ASHRAE, CABO, and Building Officials and Code Administrators International, Inc. (BOCA). These parent standards tend to be technically compatible; the requirements are usually expressed as maximum allowable overa11 thermal transmittance values $\left(U_{0}\right)$ for major envelope components and minimum allowable thermal resistance values (R) for perimeter insulation of slabs-on-grade (NCSBCS 1985). Criteria are expressed as, or drawn from graphs based on, annual heating degree days.

In the process of adopting their codes, most states with mandatory codes have modified parent standards. States will often establish state code levels for a limited number of geographic (climatic) zones to avoid the problems of enforcing a code that could fluctuate substantially from one community to another. Other modifications, such as prescribing minimum envelope performance on the basis of heating and appliances (and their efficiencies), are often adopted. State energy codes are reviewed and updated from time to time. Most states have updated the code at least once since initial adoption (NCSBCS 1985).

Several states (including California, Florida, Hawaii, Louisiana, Nevada, North Carolina, Washington, Oregon and Alaska) have developed their own codes rather than adopting modified versions of the parent codes (a)though there frequently is a perceptible relationship to the latter). Some of these codes have sophisticated compliance mechanisms using computer software; almost all have a variety of paths to compliance so as to not limit. design of and construction techniques for homes.

\subsubsection{Base Case Energy-Efficiency Requirements}

Estimation of the potential impacts of the VOLRES was based on a limited number of case studies, since the inherent flexibility of the standard permits an almost limitless variety of code packages to be developed. For each location included as a case study, the corresponding base (existing) code or level of current building practices was also determined. The following discussion provides some information on how the base efficiency levels were developed. 
As noted above, state energy codes are often expressed as performance levels for individual envelope and space conditioning components. Quite frequently, the efficiency of the wall components (opaque areas, windows and doors) is expressed as a single $U_{0}$ value, to permit tradeoffs among levels of insulation, window area, etc. However, life-cycle cost calculations for the base codes and comparison with the proposed standard required componentspecific values.

In addition, consumer demand, utility incentive programs or other factors often influence home builders in states without mandatory codes to opt for component efficiencies that exceed model code levels. (This also occurs in states with mandatory code.)

Therefore, the base case for each study location (for site-built homes) was determined by obtaining information about the most prevalent levels of energy conservation measures currently installed by builders in that location, either to meet code, or as currently practiced (for locations with no mandatory code). Sources of this information included code enforcement officials at the state and local level, prominent builders, developers and designers, utility staff and other knowledgeable persons. Three to four sources of information were sought for each location; more were used if it was difficutt to obtain a consensus.

Component levels for the base case manufactured homes were obtained in a similar manner, but the source was a survey of manufacturers conducted in the fall of 1987 by Pacific Northwest Laboratory (Nesse et a1. 1988). The levels of components installed by the surveyed manufacturers often exceeded those required to meet the Department of Housing and Urban Development's (HUD) Manufactured Homes Construction and Safety Standards (MHCSS), a mandatory minimusn required for this type of housing. 


\subsection{ECONOMIC IMPACTS OF THE PROPOSED STANDARD}

This section presents the results of the economic analysis of the proposed standard. Direct and indirect impacts of the standard are presented, as well as results of the sensitivity analysis. A detailed description of the methodology used is in Section 4.0.

\subsection{DIRECT IMPACTS OF PROPOSED STANDARD}

The direct impacts of the proposed standard have been estimated using life-cycle costs over the 15-year time horizon. The life-cycle cost is the sum of the net present value of the capital costs (or initial costs) of the energy conservation measure and the net present value of the energy costs incurred over the time horizon. Because the median turnover period for home ownership and mortgages is assumed to be seven years, the configuration generated by ARES is based on a seven-year time horizon. Society, however, continues to reap the benefits of the energy savings that occur over the life of the building. Thus, for the analysis of regional and national impacts, the net present value of the energy savings was calculated for a 15-year period.

\subsubsection{National Impacts}

Tables 3.1 and 3.2 present the energy costs, capital costs, and total life-cycle cost (LCC) of the proposed standard under alternative penetration rates for the Census regions and the United States. By calculating the lifecycle cost of new construction as currently practiced and the construction that would be required by the proposed standard, our analysis results in regional and national net benefits of the standard over a 15-year period.

For this analysis, two different penetration rates were considered: full penetration and ramped penetration. Full penetration assumes an immediate and complete adoption of the proposed standard, and for this reason, represents the most extreme case. Ramped penetration is a step-wise penetration of the proposed standard, beginning at 20 percent in 1988 and increasing by 20 percent increments until full penetration is reached in 1992. 
IABLE 3.1. Net Change of Regional and National Life-Cycle Costs (LCC), 15-Year Time Horizon, Ful1 Penetration of the Standard

\section{Year of \\ 1988}

Construction

Energy Costs

Capita! Costs

Total LCC

1989

Energy Costs

Capital Costs

Total LCC

1990

Energy Costs

Capital Costs

Total LCC

1991

Energy Costs

Capital Costs

Total LCC

1992

Energy Costs

Capital Costs

Total LCC

1993

Energy Costs

Capital Costs

Total LCC

1994

Energy costs

Capital Costs

Total LCC

1995

Energy Costs

Capital Costs

Total LCC

1996-2000

Energy Costs

Capital Costs

Total LCC

2001-2005

Energy Costs

Capital costs

\begin{tabular}{|c|c|c|c|c|}
\hline Northeast & South & North Central & West & U.S. \\
\hline $\begin{array}{l}(696,006)^{(a)} \\
359,766 \\
(336,240)\end{array}$ & $\begin{array}{c}(717,551) \\
420,296 \\
(297,256)\end{array}$ & $\begin{array}{c}(300,079) \\
89,021 \\
(211,058)\end{array}$ & $\begin{array}{c}(236,428) \\
150,945 \\
(85,484)\end{array}$ & $\begin{array}{c}(1,950,065) \\
1,020,027 \\
(930,038)\end{array}$ \\
\hline $\begin{array}{c}(740,579) \\
382,898 \\
(357,681)\end{array}$ & $\begin{array}{c}(703,872) \\
412,055 \\
(291,818)\end{array}$ & $\begin{array}{c}(281,724) \\
83,894 \\
(197,830)\end{array}$ & $\begin{array}{l}(226,189) \\
144,141 \\
(82,048)\end{array}$ & $\begin{array}{c}(1,952,364) \\
1,022,987 \\
(929,377)\end{array}$ \\
\hline
\end{tabular}

$\begin{array}{cc}(802,694) & (779,869) \\ 414,992 & 456,479 \\ (387,702) & (323,390)\end{array}$

$(296,762)$
88,259

$(252,771)$

161,033

$(91,738)$

$(2,132,096)$

$(208,503)$

$(263,251)$

167,646

$(95,605)$

$1,120,763$

$\begin{array}{rr}(801,505) & (818,236) \\ 414,360 & 478,983\end{array}$

$(387,146)$

$(339,253)$

$(301,209)$
89,483
$(211,726)$

$(842,924)$

493,246

$(349,678)$

$(290,725)$
86,485

$(267,266)$

170,265

$(97,001)$

$(2,195,955$

411,013
$(384,027)$

(204,241)

$(808,480)$
477,381

$(331,100)$

$(200,216)$
57,600

$(142,616)$

$(297,904)$

190,077

$(107,828)$

$(1,866,802)$

289,628

$(331,100)$

$(515,273)$

266,422

$(816,065)$

482,089

$(333,976)$

$(184,646)$
52,914

(131, 732)

$(266,302)$

169,537

$(96,766)$

$(2,184,202)$

$1,750,472$

$(1,033,730)$

(483, 110)

249,799

$(233,311)$

$(855,120)$
505,812
$(349,308)$

(176, 862)

50,571

$(126,290)$

$(248,434)$

158,005

$(90,429)$

$(1,763,525)$

$(799,338)$

$$
\begin{gathered}
(2,683,573) \\
1,387,523
\end{gathered}
$$

$(3,750,091)$

$2,219,708$
$(1,530,383)$
$(1,015,783)$
293,846

$(1,409,193)$

883,061

$(526,132)$

$(8,858,640)$

$4,784,137$

$(1,296,051)$

(3, 623,586)

$(847,624)$
245,794
$(601,829)$
$(1,048,427)$
669,239

(370.188)

$(7,797,316)$

$(2,277,678)$
$1,177,864$

$2,149,670$

$(1,473,917)$

4, 242, 667

(a) Values in parentheses are negative values.

(b) Totals may not equal sum of components due to independent rounding. 
TABLE 3.2. Net Change of Regional and National Life-Cycle Costs (LCC), 15-Year Time Horizon, Ramped Penetration of the Standard

Year of
Constr
1988
Energy

Energy Costs

Capital Costs

Total LCC

1989

Energy Costs

Capital Costs

Total LCC

1990

Energy Costs

Capital Costs

Total LCC

1991

Energy Costs

Capital Costs

Total LCC

1992

Energy Costs

Capital Costs

Total L.CC

1993

Energy Costs

Capital Costs

Total LCC

1994

Energy Costs

Capital Costs

Total LCC

1995

Energy costs

Capital Costs

Total LCC

19\%-2000

Energy Costs

Capital costs

Total LCC

2001-2005

Energy Costs

Capital Costs

Total LCC

Net Present Value in \$ Thousands (b)
Northeast

$(139,201)^{(a)}$

71,953

$(67,248)$

$(143,510)$
84,059

$(59,451)$

$\{60,016\}$
17,804

$(42,212)$

(47, 286)

30,189

$(390,013)$

$(17,097)$

(186, 008)

$(2 \%, 232)$

$(281,549)$

164,822

$(116,727)$

(112,689)

33,557

$(79,132)$

(90.475)

57.656

$(32,819)$

$(780,946)$

(943,073)

(467,921)

273,887

(178,057)

52,956

$(151,662)$

9,620

$(55,043)$

$(1,279,257)$

248,995
$(232,621)$

$(194,034)$

$(125,102)$

$(654,589)$
383,187

$(240,968)$

71,587

$(271,402)$

$(169,381)$

$(210,601)$

134,116

$(76,484)$

409, 195

(371, 51$)$

$(309,716)$

(795,039)

$(842,924)$

$(290,725)$

(267.266)

170,265

$(97,001)$

672,458

411,013
$(384,027)$

$(349,678)$

(204, 241)

$(560,201)$

289,628

$(808,480)$

477,381

$(200,216)$

57,600

$(297,904)$

190,077

(107,828)

$(1,747,361)$

920,378

(B26,984)

$(270,573)$

$(331,100)$

$(142,616)$

$(515,273)$

266,422

$(248,851)$

(816,065)

482,089

$(333,976)$

$(184,646)$

52,914

$(266,302)$

169,537

(9.766)

$(2,195,955)$

$1,161,009$

$(1,034,946)$

$(483,110)$

$(855,120)$

505,812

$(349,308)$

(176, 862)

$(248,434)$

158,005

$(90,429)$

$(1,866,802)$

$1,014,686$

(852,116)

(233,311)

50,571
$(126,290)$

$(1,782,287)$

970,963

(811,324)

(2, 683, 573)

$(3,750,091)$

$(1,015,783)$

293,846

$(1,409,193)$

883,061

$(526,132)$

(1, 763, 525)

964,187

(799, 338)

$1,387,523$
$(1,296,051)$

$(1,530,383)$

$(721,937)$

$(2,277,678)$

$(3,623,586)$

(847,624)

$(1,048,427)$

669,239

$(379,188)$

$(1,473,917)$

(601,829)

$(1,099,714)$

(379, 1898

$(8,858,640)$

4, 784,137

$(4,074,503)$

(a) Values in parentheses are negative values.

(b) Totals may not equal sum of components due to independent rounding. 
The national net effect of the standard, assuming its immediate and full penetration, ranges from nearly $\$ 930$ million in net benefit for 1988 construction to $\$ 1035$ million for 1992 construction. This net effect is based on the net present value of energy savings and capital costs for each year over the life cycle of 15 years. In 1992 construction, the year with the largest net effect, the capital costs of construction to comply with the standard are approximately $\$ 1.2$ billion. The energy savings accrued over the 15-year period are nearly $\$ 2.2$ billion. The difference represents a net benefit of $\$ 1.0$ bilition.

Because the standard is voluntary, the net benefits were al so calculated assuming a ramped penetration of the standard. The national net effect of the standard ranges from nearly $\$ 186$ million in net benefit for construction in 1988 to $\$ 1035$ million for cunstruction in 1992. (Ful1 penetration of the standard does not occur until 1992.)

\subsubsection{Regional Impacts}

The standard creates a net benefit for all Census regions, as shown in Tables 3.1 and 3.2. Assuming full penetration of the standard, the Northeast receives the greatest benefit until 1993 when the net benefits in the South overtake those of the Northeast. The net benefit to the Northeast increases from $\$ 336$ million for 1988 construction to $\$ 384$ billion in 1992 , after which the net benefit drops steadily until the 2001 to 2005 construction period when it reach $\$ 220$ million. The West receives the smallest benefit of a1l regions until 1993 when its benefits become greater than those of the North Central region. In the construction period 2001 to 2005, the net benefit in the West increases beyond that of the North Central region. In relative magnitude, the Western region's net benefit is approximately 25 percent of the Northeast's net benefit until 1993 when the West's share of the total U.S. benefit increases substantially. Changes in the relative share of costs and benefits is attributable to changes in forecast housing for each region.

\subsubsection{Sensitivity Analysis Results}

The following subsection describes the results of the sensitivity analysis performed on fuel prices, the time horizon, and the discount rate (a)ternative investment rate). 


\section{Fue1 Prices}

An extensive analysis of the sensitivity of ARES and the resulting 1 ifecycle cost to fuel prices was performed. Fuel prices were increased and decreased by 50 percent in the ARES runs, and the new life-cycle cost was calculated for the ARES-configured housing using the increased and decreased fuel prices. As would be anticipated, ARES is sensitive to these major changes in fue 1 prices.

When fue 1 prices were decreased 50 percent, the ARES-configured housing consistently fell below the current practice in terms of energy-efficiency standards. In other words, a 50 percent decrease in current fuel prices could result in less energy-efficient construction under the proposed standard than is currently being built under state codes. If the proposed standard remains voluntary and coexists with current state codes, (i.e., current state codes remain mandatory) the effect of the proposed standard under the decreased fuel price scenario could be $n i 1$, as the more stringent current codes would take precedence and mandate the current (higher) energyefficiency standards.

An increase in fuel prices of 50 percent, however, would have substantial effects under the proposed standard. Table 3.3 presents the resulting energy savings and capital costs when fuel prices are increased 50 percent. In summary, an increase in fuel prices would increase the national net benefit of the proposed standard substantially. That is, the increase in fuel prices results in substantially higher energy savings which exceed the increase in capital costs. The national net benefit reaches its highest level for construction in 1992 with a net benefit of $\$ 2.2$ billion. This net benefit is composed of $\$ 2.0$ billion in increased capital costs and $\$ 4.2$ billion in decreased energy costs.

For all regions, the standard results in a net benefit under increased fuel prices. The Southern region's net benefit exceeds the benefit received by the other regions. By comparing the net benefit under increased fue 1 prices to the net benefit of the proposed standard under current fuel prices, the North Central and Western regions show the greatest increase in capital costs and energy savings when fue] prices increase. 
TABLE 3.3. Net Change of Regional and National Life-Cycle Costs (LCC), 15-Year Time Horizon, Ful1 Penetration of the Standard, Fuel Prices Increased by $50 \%$

Year of Construction

1988

Energy costs

Capital Costs Total LCC

1989

Energy Costs

Capital Costs Total LCC

1990

Energy Costs

Cepital Costs

Total LCC

1991

Energy Costs

Capi tal Costs

Total LCC

1992

Energy Costs

Capital Costs

Total ICC

1993

Energy Costs

Capital Costs

Total LCC

1994

Energy Costs

Capital Costs

Total LCC

1995

Energy Costs

Capi tal Costs Total LCC

1996-2000

Energy Costs

Capital Costs Total LCC

2001-2005

Energy Costs

Capital Costs

Total LCC

$\begin{array}{lll} & \text { Net Present Value in } \$ \text { Thousands } & (b) \\ \text { Northeast } & \text { South North Central Hest }\end{array}$

\begin{tabular}{ccccc}
\hline Northeast & South & North Central & West & U.S. \\
\cline { 3 - 5 } & & & & \\
& & & & \\
$(1,103,959)^{(a)}$ & $(1,298,488)$ & $(781,243)$ & $(538,810)$ & $(3,722,500)$ \\
502,973 & 618,438 & 303,521 & 319,995 & $1,744,926$ \\
$(600,986)$ & $(680,050)$ & $(477,722)$ & $(218,815)$ & $(1,977,573)$
\end{tabular}

$(1,177,418)$

$(734,225)$

$(514,546)$

$(3,700,545)$

532,801

607,002

286,135

303,554

$1,729,492$

$(644,618)$

$(667,353)$

$(448,090)$

$(210,992)$

$(1,971,053)$

\section{$(1,275,547)$}

578,028

$(1,412,123)$

672,640
$(739,483)$

$(7 / 3,147)$

$(574,852) \quad(4,035,668)$

$300,992 \quad 338,771 \quad 1,890,431$

$(472,155) \quad(236,081) \quad(2,145,237)$

\section{$(1,273,128)$}

577,629

$(695,500)$

$(1,481,468)$
705,659

$(784,495)$
305,137

$(598,463)$

352,197

$(246,266)$

$(4,137,554)$

$(479,358)$

$1,940,622$

$(775,809)$

$(1,262,729)$

$(1,526,680)$

$(607,808)$

$(4,154,686)$

573,080

727,243

$(799,438)$

294,945

$(462,524)$

$(249,636)$

$1,953,440$

$(2,201,247)$

\section{$(909,030)$}

411,455

$(1,477,555)$

(542,261)

$(692,486)$

429,688

$(3,621,332)$

$(497,575)$

$(747,125)$

223,204

$(262,798)$

(1, 826,495$)$

\section{$(835,622)$}

377,369

$(458,253)$

$(1,489,409)$
735,839
$(753,570)$

$(501,752)$

206,591

$(618,953)$

382,905

$(236,049)$

$(3,445,137)$

$(294,561)$

$1,702,705$

(783,319)

$(1,555,001)$

$(480,598)$

$(577,391)$

$(1,742,432)$

353,503

766,968

198,254

356,714

$(3,396,310)$

$(282,344)$

$(220,677)$

$1,675,440$

$(1,720,870)$

$$
\begin{array}{ccccc}
(4,352,454) & (6,806,382) & (2,742,830) & (3,272,574) & (17,174,240) \\
1,966,400 & 3,354,158 & 1,127,325 & 1,981,281 & 8,429,164 \\
(2,386,054) & (3,452,224) & (1,615,505) & (1,291,293) & (8,745,076) \\
& & & & \\
(3,687,188) & (6,534,525) & (2,285,718) & (2,437,153) & (14,944,585) \\
1,654,000 & 3,210,647 & 938,721 & 1,513,159 & 7,316,526 \\
(2,033,189) & (3,323,879) & (1,346,997) & (923,995) & (7,628,059)
\end{array}
$$

(a) Values in parentheses are negative values,

(b) Totals may not equal sum of components due to independent rounding. 


\section{Alternative Investment Rate}

The choice of the alternative investment rate, or social discount rate, used to calculate the net benefit of the proposed standard also affects the national net benefit. If the default discount rate (alternative investment rate) of 5.5 percent is used in ARES, but the life-cycle cost of that house is calculated using a different social discount rate to more accurately reflect society's discount rate in the economic analysis, the resulting life-cycle cost calculation is affected. Sensitivity runs reveal that if a 4 percent discount rate is selected in lieu of the 5.5 percent discount rate in the 1 ife-cycle cost calculation, energy costs would increase by 5 percent. This is also true for energy costs in the base case. There is a net increase in savings when changing from the 5.5 percent to the 4.0 percent discount rate, that is, the difference between energy savings due to the proposed standard and current practice would increase. On the other hand, if the social discount rate was 10 percent, energy costs would be 15 percent lower than calculated (savings would decrease). Because the capital costs are incurred in the construction of the housing, they are not discounted; therefore, the capital costs would not be affected by the choice of the social discount rate.

Time Horizon

The time horizon over which capital and energy costs are calculated also affects the total life-cycle cost. As presented in Table 3.4, a net cost to society results when the life-cycle cost is calculated for 7 years, compared with the net benefit that occlirs under a 15-year time horizon.

The capital costs are the same under the 7- and 15-year horizons, because these costs are incurred by society at construction. The net present value of the stream of energy savings under the 7-year horizon, however, is decreased substantially. For this reason, the proposed standard creates a net cost to society in all construction years under the 7-year time horizon. This cost ranges from $\$ 58 \mathrm{million}$ in 1988 to $\$ 94.2 \mathrm{million}$ in 1995 . Again, the shortened time horizon decreases the energy savings, while the capital costs incurred in complying with the standard do not change. 
IABLE 3.4. Net Change of Regional and National Life-Cycle Costs (LCC), 7-Year Time Horizon, Full Penetration of the Standard

\begin{tabular}{|c|c|c|c|c|c|}
\hline \multirow{2}{*}{$\frac{\text { Year of }}{\text { Construction }}$} & \multicolumn{5}{|c|}{ Net Present Value in \$ Thousands } \\
\hline & Northeast & South & North Central & Hest & $\underline{\text { U.S.S. }}$ \\
\hline $\begin{array}{l}1988 \\
\text { Energy Costs } \\
\text { Capital Costs } \\
\text { Tota! LCC }\end{array}$ & $\begin{array}{c}(343,368)^{(a)} \\
359,766 \\
16,398\end{array}$ & $\begin{array}{c}(353,997) \\
420,296 \\
66,299\end{array}$ & $\begin{array}{c}(148,041) \\
89,021 \\
(59,020)\end{array}$ & $\begin{array}{c}(196,639) \\
150,945 \\
34,305\end{array}$ & $\begin{array}{c}(962,045) \\
1,020,027 \\
57,982\end{array}$ \\
\hline $\begin{array}{l}1989 \\
\text { Energy Costs } \\
\text { Capital Costs } \\
\text { Total LCC }\end{array}$ & $\begin{array}{c}(365,357) \\
382,898 \\
17,541\end{array}$ & $\begin{array}{c}(347,248) \\
412,055 \\
64,806\end{array}$ & $\begin{array}{c}(138,985) \\
83,894 \\
(55,092)\end{array}$ & $\begin{array}{c}(111,588) \\
144,141 \\
32,553\end{array}$ & $\begin{array}{r}(963,179) \\
1,022,987 \\
59,808\end{array}$ \\
\hline $\begin{array}{l}1990 \\
\text { Energy Costs } \\
\text { Capitel Costs } \\
\text { Total LCC }\end{array}$ & $\begin{array}{c}(396,001) \\
414,992 \\
18,991\end{array}$ & $\begin{array}{c}(384,740) \\
456,479 \\
71,738\end{array}$ & $\begin{array}{c}\{146,405\} \\
88,259 \\
(58,145)\end{array}$ & $\begin{array}{c}(124,702) \\
161,033 \\
36,331\end{array}$ & $\begin{array}{c}(1,051,848) \\
1,120,763 \\
68,915\end{array}$ \\
\hline $\begin{array}{l}1991 \\
\text { Energy Costs } \\
\text { Capital Costs } \\
\text { Total LCC }\end{array}$ & $\begin{array}{c}(395,415) \\
414,360 \\
18,945\end{array}$ & $\begin{array}{c}(403,669) \\
478,983 \\
75,315\end{array}$ & $\begin{array}{c}(148,599) \\
89,483 \\
(59,115)\end{array}$ & $\begin{array}{l}(129,872) \\
167,646 \\
37,773\end{array}$ & $\begin{array}{c}(1,077,554) \\
1,150,472 \\
72,918\end{array}$ \\
\hline $\begin{array}{l}1992 \\
\text { Energy Costs } \\
\text { Capital Costs } \\
\text { Total LCC }\end{array}$ & $\begin{array}{c}(392,225) \\
411,013 \\
18,788\end{array}$ & $\begin{array}{c}(415,848) \\
493,246 \\
77,398\end{array}$ & $\begin{array}{c}(143,426) \\
86,485 \\
(56,942)\end{array}$ & $\begin{array}{c}(137,853) \\
170,265 \\
38,412\end{array}$ & $\begin{array}{c}(1,083,352) \\
1,161,009 \\
77,657\end{array}$ \\
\hline $\begin{array}{l}1993 \\
\text { Energy Costs } \\
\text { Capital Costs } \\
\text { Total LCC }\end{array}$ & $\begin{array}{c}(276,369) \\
289,628 \\
13,259\end{array}$ & $\begin{array}{c}(398,856) \\
477,381 \\
78,525\end{array}$ & $\begin{array}{c}(98,775) \\
57,600 \\
(41,175)\end{array}$ & $\begin{array}{c}(146,968) \\
190,077 \\
43,109\end{array}$ & $\begin{array}{c}(920,968) \\
1,014,686 \\
93,718\end{array}$ \\
\hline $\begin{array}{l}1994 \\
\text { Energy Costs } \\
\text { Capital Costs } \\
\text { Total LCC }\end{array}$ & $\begin{array}{c}(254,205) \\
266,422 \\
12,218\end{array}$ & $\begin{array}{c}(402,598) \\
482,089 \\
79,492\end{array}$ & $\begin{array}{c}(91,093) \\
52,914 \\
(38,179)\end{array}$ & $\begin{array}{c}(131,378) \\
169,537 \\
38,159\end{array}$ & $\begin{array}{c}(879,273) \\
970,963 \\
91,689\end{array}$ \\
\hline $\begin{array}{l}1995 \\
\text { Energy Costs } \\
\text { Capital Costs } \\
\text { Total LCC }\end{array}$ & $\begin{array}{c}(238,337) \\
249,799 \\
11,461\end{array}$ & $\begin{array}{c}(421,865) \\
505,812 \\
83,947\end{array}$ & $\begin{array}{c}(87,253) \\
50,571 \\
(36,682)\end{array}$ & $\begin{array}{c}(122,562) \\
158,005 \\
35,443\end{array}$ & $\begin{array}{c}(870,017) \\
964,187 \\
94,170\end{array}$ \\
\hline $\begin{array}{l}1996-2000 \\
\text { Energy Costs } \\
\text { Capital Costs } \\
\text { Total LCC }\end{array}$ & $\begin{array}{c}(1,323,914) \\
1,387,523 \\
63,609\end{array}$ & $\begin{array}{c}(1,850,069) \\
2,219,708 \\
369,638\end{array}$ & $\begin{array}{c}(501,126) \\
293,846 \\
(207,280)\end{array}$ & $\begin{array}{l}(695,211) \\
883,061 \\
187,850\end{array}$ & $\begin{array}{c}(4,370,321) \\
4,784,137 \\
413,817\end{array}$ \\
\hline $\begin{array}{l}2001-2005 \\
\text { Energy Costs } \\
\text { Capital Costs } \\
\text { Iotal LCC }\end{array}$ & $\begin{array}{c}(1,123,670) \\
1,177,964 \\
54,294\end{array}$ & $\begin{array}{c}(1,787,660) \\
2,149,670 \\
362,010\end{array}$ & $\begin{array}{c}(418,167) \\
245,794 \\
(172,372)\end{array}$ & $\begin{array}{c}(517,231) \\
669,239 \\
152,008\end{array}$ & $\begin{array}{c}(3,846,727) \\
4,242,667 \\
395,940\end{array}$ \\
\hline
\end{tabular}

(a) Values in parentheses are negative values.

(b) Totals may not equal sum of components due to independent rounding. 
The time horizon of 30 years, one that more closely approximates the physical life of the average home, creates substantial national net benefits. The life-cycle costs in Table 3.5 show that energy savings over 30 years increase considerably. For example, 1992 construction would increase savings to nearly $\$ 4.0$ billion while capital costs remain at $\$ 1.1$ billion. This overstated net benefit of $\$ 2.8$ billion must be adjusted because of several factors that must be taken into account when using a 30-year horizon. The decreased efficiency of the aging home (packed insulation, leaking window casings, etc.) would decrease the calculated energy savings, and the replacement of heating and cooling equipment that would be required over the 30 -year period would increase capital costs. On the other hand, as the equipment is replaced over the 30-year time horizon, technologicaliy more advanced equipment could increase energy savings and perhaps costs, as wel1. These factors are not included in the analysis of the 30 -year life-cycle cost of the proposed standard.

\section{Homeowners' Perspective}

The calculation of the impacts of the proposed standard on the homeowner, the perspective taken by ARES, relies on a different method of analysis from that used to calculate the impacts on society. The homeowner faces a different iife-cycle cost because of changes in income and property taxes, loan fees, down payment, and the resale value that occur when capital improvements are incorporated into the new residence. (See Section 4.3 for a detailed discussion of the difference in perspective.) Secondly, because the median length of home ownership is seven years, the life-cycle cost of energy and capital costs is calculated for a 7-year time horizon, instead of the 15-year time horizon used to calculate the benefits in Section 3.1.

In Table 3.6, the results of the Tife-cycle cost calculation for the homeowner are presented. For all years of construction, the proposed standard would generate a net benefit for homeowners. For 1992 construction, the greatest net benefit accrues to homeowners. While capital costs reach $\$ 575.8$ million, the net present value of the energy savings reaches $\$ 1.1$ bilTion over the seven-year time horizon. This results in a net benefit of $\$ 507.5$ million to homeowners for 1992 construction. 
TABLE 3.5. Net Change of Regional and National Life-Cycle Costs (LCC), 30-Year Time Horizon, Full Penetration of the Standard

\section{8}

Year of Construction

Energy Costs

Capital Costs

Total LCC

1989

Energy Costs

Copital Costs

Total LCC

1990

Energy Costs

Capital Costs

Total LCC

1991

Energy Costs

Capital Costs

Total LCC

1992

Energy Costs

Capital Costs

Total LCC

1993

Energy Costs

Capital Costs

Total LCC

1994

Energy Costs

Capital Costs

Total LCC

1995

Energy Costs

Capital Costs

Total LCC

1996-2000

Energy Costs

Capital Costs

Total LCC

2001-2005

Energy Costs

Capi tal Costs

rotal LCC

\begin{tabular}{cc} 
& Net Pres \\
\hline Northeast & South \\
& \\
& \\
$(1,257,241)^{\text {(a) }}$ & $(1,296,159)$ \\
359,766 & 420,296 \\
$(897,475)$ & $(875,864)$
\end{tabular}

North Central

$\mathrm{ds}^{(b)}$

Hest

$$
\begin{gathered}
(542,051) \\
89,021
\end{gathered}
$$

$(453,031)$

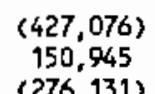

$(3,522,527)$

$(1,337,756)$

382,898

$(1,271,449)$
412,055
$(859,395)$

(508,895)

(425,002)

(276,

$1,020,027$

$(954,858)$

\section{$(1,449,958)$}

414,992

$(1,408,727)$

456,479

(952,248)

$(536,060)$
88,259
$(447,801)$

$(408,579)$

144,141

$(264,438)$

$(3,526,680)$

$3,022,987$

$(2,503,693)$

$(1,034,966)$

$$
\begin{gathered}
(1,447,811) \\
414,360 \\
(1,033,451)
\end{gathered}
$$
$(1,478,032)$
478,983
$(999,049)$

$$
\begin{gathered}
(544,094) \\
89,483
\end{gathered}
$$

$(454,611)$

$(456,596)$
161,033

$(295,563)$

(3, 851,341)

$1,120,763$

$(2,730,578)$

$$
\begin{gathered}
(1,436,131) \\
411,013 \\
(1,025,118)
\end{gathered}
$$
$(1,522,628)$
493, 246

$(1,029,381)$
$(525,156)$
86,485

(438,671)

$(4 \pi 5,527)$

167,646

$(3,945,464)$

(307,881)

$1,150,472$

$(2.794,992)$
$(1,011,926)$
289,628
$(722,298)$
$(1,460,410)$
477,381
(983,029)

$(361,664)$
57,600
$(304,063)$

(482,780)

170,265

$(312,515)$

$(3,966,695)$

$1,161,009$

$(2,805,686)$

$$
\begin{gathered}
(930,770) \\
266,422 \\
(664,348)
\end{gathered}
$$

$$
\begin{gathered}
(1,474,111) \\
482,089 \\
(992,022)
\end{gathered}
$$

$$
\begin{gathered}
(333,539) \\
52,914 \\
(280,624)
\end{gathered}
$$

$(538,124)$

190,077

$(348,047)$

$(3,372,123)$

$1,014,686$

$(2,357,438)$

$(481,039)$

169,537

$(311,502)$

$(3,219,459)$

970,963

$(2,248,497)$

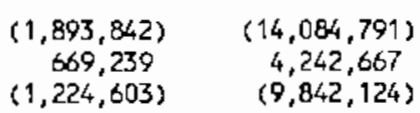

$$
\begin{gathered}
(872,672) \\
249,799 \\
(622,874)
\end{gathered}
$$

$(1,544,658)$
505,812
$(1,038,845)$

$(319,476)$
50,571
$(268,905)$

$$
\begin{gathered}
(4,847,510) \\
1,387,523 \\
(3,459,988)
\end{gathered}
$$

$(6,74,029)$

$2,219,708$

$(4,554,322)$
$(1,834,875)$
293,846

$(1,541,028)$

$$
(4,114,316)
$$

$(6,545,516)$

$1,177,964$

$(2,936,352)$

$2,149,670$

$(4,395,846)$

(448, 762)

158,005

$(290,757)$

$(3,185,568)$

964,187

$(2,221,381)$

$(2,545,516)$

883,061

$(1,662,455)$

$(16,001,930)$

$4,784,137$

$(11,217,792)$

(a) Values in parentheses are negative values.

(b) Totals may not equal sum of components due to independent rounding. 
TABLE 3.6. Net Change of Regional and National Life-Cycle Costs (LCC), 7-Year Time Horizon, Full Penetration of the Standard, Homeowners' Perspective

\begin{tabular}{|c|c|c|c|c|c|}
\hline \multirow[b]{2}{*}{$\frac{\text { Year of }}{\text { Construction }}$} & \multicolumn{5}{|c|}{ Net Present Value in $\$$ Thousands (b) } \\
\hline & Northeast & South & North Central & West & U.S. \\
\hline $\begin{array}{l}1988 \\
\text { owner's Capital cost } \\
\text { Energy Costs } \\
\text { Owner's Total LCC }\end{array}$ & $\begin{array}{c}180,109 \\
(343,368)(a) \\
(163,258)\end{array}$ & ) $\begin{array}{c}205,054 \\
(353,997) \\
(148,943)\end{array}$ & $\begin{array}{c}47,271 \\
(148,041) \\
(100,770)\end{array}$ & $\begin{array}{c}74,003 \\
(116,639) \\
(42,636)\end{array}$ & $\begin{array}{c}506,438 \\
(962,045) \\
(455,607)\end{array}$ \\
\hline $\begin{array}{l}1989 \\
\text { Owner's Capital Cost } \\
\text { Energy Costs } \\
\text { Ouner's Total LCC }\end{array}$ & $\begin{array}{c}191,634 \\
(365,357) \\
(173,724)\end{array}$ & $\begin{array}{c}201,053 \\
(347,248) \\
(146,195)\end{array}$ & $\begin{array}{r}44,557 \\
(138,985) \\
(94,428)\end{array}$ & $\begin{array}{c}70,680 \\
(111,589) \\
(40,908)\end{array}$ & $\begin{array}{c}507,924 \\
(963,179) \\
(455,255)\end{array}$ \\
\hline $\begin{array}{l}1990 \\
\text { Ouner's Capital cost } \\
\text { Energy Costs } \\
\text { Ouner's Total LCC }\end{array}$ & $\begin{array}{c}207,709 \\
(396,001) \\
(188,292)\end{array}$ & $\begin{array}{c}222,734 \\
(384,740) \\
(162,006)\end{array}$ & $\begin{array}{c}46,873 \\
(146,405) \\
(99,532)\end{array}$ & $\begin{array}{r}78,966 \\
(124,702) \\
(45,736)\end{array}$ & $\begin{array}{r}556,282 \\
(1,051,848) \\
(495,566)\end{array}$ \\
\hline $\begin{array}{l}1991 \\
\text { Owner's Copital cost } \\
\text { Energy Costs } \\
\text { Owner's Total LCC }\end{array}$ & $\begin{array}{c}207,403 \\
(395,415) \\
(188,011)\end{array}$ & $\begin{array}{c}233,711 \\
(403,669) \\
(169,958)\end{array}$ & $\begin{array}{c}47,520 \\
(148,599) \\
(101,078)\end{array}$ & $\begin{array}{c}82,211 \\
(129,872) \\
(47,661)\end{array}$ & $\begin{array}{r}570,846 \\
(1,077,554) \\
(506,708)\end{array}$ \\
\hline $\begin{array}{l}1992 \\
\text { Owner's Capital cost } \\
\text { Energy Costs } \\
\text { Owner's Total LCC }\end{array}$ & $\begin{array}{c}205,731 \\
(392,225) \\
(186,494)\end{array}$ & $\begin{array}{c}240,687 \\
(415,848) \\
(175,161)\end{array}$ & $\begin{array}{c}45,931 \\
(143,426) \\
(97,496)\end{array}$ & $\begin{array}{r}83,493 \\
(131,853) \\
(48,360)\end{array}$ & $\begin{array}{r}575,841 \\
(1,083,352) \\
(507,511)\end{array}$ \\
\hline $\begin{array}{l}1993 \\
\text { Owner's Capital cost } \\
\text { Energy Costs } \\
\text { Ouner's Total LCC }\end{array}$ & $\begin{array}{c}144,960 \\
(276,369) \\
(131,410\rangle\end{array}$ & $\begin{array}{c}232,674 \\
(398,856) \\
(166,182)\end{array}$ & $\begin{array}{c}30,537 \\
(98,775) \\
(68,237)\end{array}$ & $\begin{array}{r}93,194 \\
(146,968) \\
(53,774)\end{array}$ & $\begin{array}{c}501,365 \\
(920,968) \\
(419,603)\end{array}$ \\
\hline $\begin{array}{l}1994 \\
\text { Owner's Capital Cost } \\
\text { Energy Costs } \\
\text { Owner's Total LCC }\end{array}$ & $\begin{array}{c}133,332 \\
(254,205) \\
(120,873)\end{array}$ & $\begin{array}{c}234,950 \\
(402,598) \\
(167,648)\end{array}$ & $\begin{array}{c}28,048 \\
(91,093) \\
(63,046)\end{array}$ & $\begin{array}{c}83,141 \\
(131,378) \\
(48,236)\end{array}$ & $\begin{array}{l}479,470 \\
(879,273) \\
(399,803)\end{array}$ \\
\hline $\begin{array}{l}1995 \\
\text { Owner's Capital Cost } \\
\text { Energy Costs } \\
\text { Owner's Total LCC }\end{array}$ & $\begin{array}{c}125,008 \\
(238,337) \\
(113,329)\end{array}$ & $\begin{array}{c}246,456 \\
(421,865) \\
(175,409)\end{array}$ & $\begin{array}{c}26,803 \\
(87,253) \\
(60,450)\end{array}$ & $\begin{array}{c}77,493 \\
(122,562) \\
(45,069)\end{array}$ & $\begin{array}{c}4 \pi, 761 \\
(870,017) \\
(394,256)\end{array}$ \\
\hline $\begin{array}{l}1996-2000 \\
\text { Owner's Capital cost } \\
\text { Energy Costs } \\
\text { Owner's Total LCC }\end{array}$ & $\begin{array}{c}694,402 \\
(1,323,914) \\
(629,512)\end{array}$ & $\begin{array}{r}1,081,424 \\
(1,850,069) \\
(768,646)\end{array}$ & $\begin{array}{c}155,829 \\
(501,126) \\
(345,298)\end{array}$ & $\begin{array}{c}433,728 \\
(695,211) \\
(261,484)\end{array}$ & $\begin{array}{c}2,365,382 \\
(4,370,321) \\
(2,004,939)\end{array}$ \\
\hline $\begin{array}{l}2001-2005 \\
\text { Owner's Capital Cost } \\
\text { Energy Costs } \\
\text { Owner's Total LCC }\end{array}$ & $\begin{array}{c}589,340 \\
(1,123,670) \\
(534,330)\end{array}$ & $\begin{array}{r}1,046,894 \\
(1,787,660) \\
(740,765)\end{array}$ & $\begin{array}{c}130,362 \\
(418,167) \\
(287,804)\end{array}$ & $\begin{array}{c}328,112 \\
(517,231) \\
(189,119)\end{array}$ & $\begin{array}{c}2,094,708 \\
(3,846,727) \\
(1,752,019)\end{array}$ \\
\hline
\end{tabular}

(a) Values in parentheses are negative values.

(b) Totals may not equal sum of components due to independent rounding. 


\subsection{OUTPUT AND EMPLOYMENT IMPACTS}

In this section, the total impacts of the proposed standard have been estimated in terms of changes in output and employment, industry impacts, and institutional impacts. In this discussion of output and employment, the perspective of analysis changes. A switch is made for the resource perspective used above, to an economic-effects perspective. Had funding allowed a simultaneous approach, these would be flip sides of the same coin: additional resource use (a cost) generates additional output and employment (a benefit), while resource savings (a benefit) reduces employment and output (a cost). Only in the most cursory way are output and employment effects treated, and then without due consideration for the implication of these additional resource savings (use) in other sectors of the economy.

Total impacts were estimated using the 1977 U.S. input-output (I/0) structure of the economy. The difference between capital costs that would be incurred in the construction of the ARES-configured building and those of the buildings constructed according to current practice are introduced as changes in final demands. These changes are then forced through the $I / 0$ table to simulate the effect of the direct costs of the standard on the U.S. economy. The changes in energy expenditures, al located to the different fuels, are likewise introduced as changes in final demand and used to simulate the changes that result from the proposed standard. These changes in industry output, in turn, are multiplied by labor-intensity for each industry to yield the change in employment that would result from the standard.

The total (direct plus indirect) impacts of the proposed standard are assessed in terms of the additional output and employment that would result from the increase in capital costs and the loss of output and employment that would occur because of lower energy expenditures. The 1977 I/0 table indicates that for every $\$ 100$ million of new residential construction, $\$ 197 \mathrm{mil}$ lion of additional output is generated. On the other hand, for every $\$ 100$ milition of residential energy savings, output is decreased by $\$ 212 \mathrm{mi}$ lion. The employment effects are as follows: for every $\$ 100$ million of new construction, 2760 jobs are generated, and for every $\$ 100 \mathrm{mi} 77$ ion of energy savings, 1950 jobs are 70 st. 
In Table 3.7, the total output and employment effects are presented by construction year, assuming full and immediate penetration of the proposed standard. The total changes in output and employment resulting from the standard are minimal compared with the entire U.S. economy. For purposes of illustration the effects of the energy savings have been assumed to occur in the year of construction, when in reality the energy savings presented in Tables 3.1 and 3.2 occur over the 15-year time horizon. In 1992, the year with the greatest total impacts, the combined effect of output changes results in a net loss of approximately $\$ 2.5$ billion in output because of the joint effect of the standard in 1992. This net decrease in output is the difference between a $\$ 2.2$ billion increase in output resulting from increased capital expenditures for construction and a $\$ 4.7$ billion decrease in output resulting from lower energy expenditures. The greatest total effect on employment results from 1991 construction and shows a loss of over 10,800 jobs. This net loss is the difference between an increase of 31,800 jobs from increased capital costs and a loss of 42,600 jobs from decreased energy expenditures.

Even when all of the effects on output resulting from decreased energy expenditures over the 15-year period are assumed to occur in the initial year, the output change represents only 0.05 percent of the U.S. Gross National Product. If, in fact, the effects on output due to energy savings were distributed over the 15-year period, the loss of output would be greatly reduced. For example, if only the reduction in output due to the initial year of energy savings for 1988 construction is considered (as opposed to the full 15-year total), the reduced output associated with energy savings would be $\$ 616.4 \mathrm{million}$. When the reduced output from energy savings is combined with the increase in output from capital cost, the result is a net increase in output of $\$ 1.3$ billion for 1988 construction, which represents 0.03 percent of the total output of the U.S. economy.

\subsection{INDUSTRY IMPACTS}

The industries most affected by a change in construction activity are the two industries directly affected--construction and miscellaneous transportation equipment (under which manufactured housing is classified). A 


\section{TABLE 3.7. Total Impacts of the Proposed Standard, Fu11 Penetration}

Year of

Construction

1988

Due to Changes in Energy Costs

Due to Changes in Capital Costs

Net effect

1989

Dwe to Changes in Energy Costs

Due to Changes in Capita! Costs

Net effect

1990

Due to Changes in Energy Costs

Due to Changes in Capital Costs

Net effect

1991

Due to Changes in Energy Costs

Due to Changes in Capital Costs

Net effect

1992

Due to Changes in Energy Costs

Due to Changes in Capital costs

Net effect

1993

Oue to Changes in Energy costs

Due to Changes in Capital costs

Net effect

1994

Due to Changes in Energy Costs

Due to Changes in Capital Costs

Net effect

1995

Due to Changes in Energy Costs

Due to Changes in Capital Costs

Net effect

$1996-2000$

Due to Changes in Energy Costs

Due to Changes in Capital Costs

Net effect

2001-2005

Due to Changes in Energy Costs

Duc to Changes in Capital Cost's Net effect
Changes in

Gross Output (b)
(\$ thousands)

$(4,134,137)^{\text {(a) }} \quad(38,026)$

$2,009,912 \quad 28,153$

$(2,124,226) \quad(9,874)$

$(4,139,011)$

$(38,071)$

$2,015,745$
$(2,123,267)$

28,234

$(9,837)$

$(41,576)$

$(4,520,043)$

$2,208,408$

$(2,311,635)$

30,933

$(10,643)$

$(4,630,508)$

$2,266,947$

$(42,592)$

$(2,363,560)$

$(10,839)$

$(4,655,425)$

$(42,821)$

$2,287,710$

$(2,367,715)$

32,044

$(10,777)$

$\begin{array}{cc}(3,957,619) & (36,403) \\ 1,999,387 & 28,005 \\ (1,958,232) & (8,397)\end{array}$

$(3,778,449) \quad(34,755)$

$1,913,233 \quad 26,799$

$(1,865,215) \quad(7,956)$

$(3,738,673)$

$(34,389)$

$1,899,882$

26,612

$(1,838,790)$

$(7,777)$

$(18,780,317)$

$9,426,904$

$(172,743)$

$(9,353,414)$

132,042

$(40,701)$

$\begin{array}{cc}(16,530,309) & (152,048) \\ 8,359,963 & 117,098 \\ (8,170,347) & (34,950)\end{array}$

(a) Values in parentheses are negative values.

(b) Totals may not equal sum of components due to independent rounding. 
$\$ 100$ million increase in demand (distributed 88.5 percent to construction, 11.5 percent to manufactured housing) would increase gross output of construction by $\$ 90.1 \mathrm{mi} 17$ ion and manufactured housing by $\$ 11.4 \mathrm{million}$. Five other industries would have an increase in gross output of more than $\$ 4 \mathrm{mil}$ lion: wholesale trade $(\$ 7.8 \mathrm{million})$, lumber and wood products $(\$ 5.6 \mathrm{mil}$ lion), basic iron and steel ( $\$ 5.6 \mathrm{million})$, primary nonferrous metals ( $\$ 4.5$ million), and fabricated structural products $(\$ 4.8$ million). Several other industries would be affected by $\$ 2$ to $4 \mathrm{million:}$ stone and clay mining (\$2.2 milition), petroleum refining ( $\$ 2.4$ milition), rubber and miscellaneous products ( $\$ 2.7$ million) cement $(\$ 3.0 \mathrm{million})$, stone and $\mathrm{clay}$ products (\$2.1 million), other fabricated metals ( $\$ 3.2 \mathrm{million}$ ), truck transportation (\$3.1 million), retail trade $(\$ 3.6$ million) and business services $(\$ 3.9 \mathrm{mil}$ 1ion). Of the 100 producing industries contained in the input-output table used to calculate these impacts, 13 other industries had more than $\$ 1$ million increase as a result of the increase in construction activity. The employment impacts, except for the construction industry (1070 jobs of the total 2760), are negligible.

The impact of a $\$ 100$ million increase in fuel consumption is not distributed as broadly across the economy as is a change in construction activity. The $\$ 100$ million fuel consumption change was allocated $\$ 55$ million to natural gas, $\$ 30$ million to electricity, and $\$ 15$ million to petroleum products. Accordingly, the most affected industries as a result of a change of $\$ 100$ million in fuel consumption are gas utilities (\$77.5 million), electric utilities ( $\$ 32.4$ million), petroleum refining ( $\$ 17.0 \mathrm{mil1ion})$ and petroleum and natural gas mining ( $\$ 28.3 \mathrm{million})$. Onjy six other industries had increases in output in excess of $\$ 2$ milition: real estate $(\$ 8.2$ miltion), construction ( $\$ 7.8$ million), business services (\$3.7 million), mining (\$3.6 million), wholesale trade $(\$ 3.0 \mathrm{million})$ and finance and insurance (\$2.7 million). Only five other industries had increases in output greater than $\$ 1$ million. The employment impacts are largest in gas and electric utilities (550 and 295 jobs, respectively) but are quite smal1 relative to employment (about 0.1 percent in both industries). 


\subsubsection{Institutional Impacts}

The proposed standard is intended to be a voluntary guideline for the private sector construction of residential buildings. As it is not a binding standard, there are no institutional impacts that directly result from its issuance by DOE. However, adoption of the proposed standard as a mandatory code by states and local code entities could have several significant institutional effects, which are discussed below. This discussion is conjectural, since the ultimate use of the VOLRES standard cannot be predicted.

Because of the widespread existence of mandatory energy codes that stipulate efficiency levels for energy conservation measures in new residences, adoption of VOLRES (to update existing codes) is not likely to adversely impact state and local institutions. This does not imply, however, that adoption would be straightforward or politically uncontroversiai. On the contrary, adoption of and changes to state energy codes have often been accompanied by intensive lobbying by the building trades, utilities, homeowner groups, code official organizations and others. Adoption of the VOLRES standard is likely to generate at least as much political controversy as was the case with present state codes. While the large number of user-modifiable parameters in the proposed standard makes it very flexible, this feature also increases the likelihood that when the standard is adopted as a code, it will contain a number of politically-negotiated settings.

In a majority of states with mandatory codes, performance requirements for energy conservation measures are based on average statewide values for heating and cooling degree days. However, other states attempt to account for climate diversity by designating requirements by climate zone. The most prominent example of the latter is California, where code variations were developed for 14 zones. The climate zone approach is typically used to strike a balance between two principal (but somewhat contradictory) needs of energy codes--climate sensitivity and simplicity of compliance and enforcement. While the use of zones gives an energy code relatively more climate sensitivity, it also serves to limit the potential geographic variability of requirements (important to the building trades). The latter need increases 
the possibility that states will modify the climate-related flexibility of the proposed standard if they choose to adopt it to update current codes.

Adoption of a fuel-specific code such as the voLRES standard may also cause some political and institutional impacts in states where energy codes are presently fuel-blind. Most mandatory energy codes do not differentiate between energy sources, and this is becoming an increasingly common approach as states update their codes (NCSBCS 1985). Selection of appropriate fue] prices to use in ARES may also prove to be controversial, particularly if VOLRES is adopted on the basis of zones or regions within a state. While ARES is designed to create separate standards for different fuels in a given locale (to avoid giving any fuel preferential treatment), the resulting standards usually do not have identical requirements for energy conservation measures or associated life-cycle and construction costs. The cost differences may cause some change in the local market share held by a given fuel. This so-called "fuel switching" is actually the change in the heating fuels consumers are choosing for new homes.

Enforcement of the standard as part of local building codes could require different procedures than those typically used by most states for current energy codes (visual inspection and/or measurement). Compliance with the proposed standard is most easily verified if the energy conservation measure package generated by ARES is used as the code. If other compliance paths (energy budget or point system) are used, code enforcement officials may also need additional training and/or equipment (computers). However, the nature and extent of enforcement-related impacts would depend on the features of the proposed standard as adopted by state or local governments and the compliance paths that are permitted. 


\subsection{METHODOLOGY}

This section provides a detailed description of the process used to assess the economic impacts of the VOLRES standard. The subsections begin with an overview of the analytical process. New residences are assumed to be configured as if ARES were used in the design of the building. The product of this design step, the building configurations, is the topic of the second subsection. This configuration is then used to calculate life-cycle costs from society's perspective, which is explained in Section 4.3. The results of this calculation are aggregated to a national total using information about different types of building and housing forecasts for each major region within the country; direct benefits (costs) of the standard that are the product of this aggregation procedure are explained in Section 4.4. The calculation of the total (direct plus indirect) benefits (costs), using an input-output table for the U.S. economy is explained in Section 4.5. Section 4.6 then examines the sensitivity analysis that was performed regarding changes in assumptions, primarily fuel price changes, changes in the discount rate, and changes in the time horizon. The final subsection details the source of the data used in the analysis.

\subsection{OVERVIEW OF THE ANALYTICAL PROCESS}

Figure 4.1 offers a flowchart diagram of the analytical process used in this study. Given values for the set of economic parameters, ARES generates a building configuration that meets the VOLRES standard at a minimum lifecycle cost for each building type (single-family, multi-family, and manufactured housing) for a given location. Values for several parameters for this analysis are used in ARES according to the recommendations of the ASHRAE committee for Special Project 53; other economic parameter values were selected for this study in consultation with DOE and the office of Management and Budget.

A variety of locations is assessed for each buitding type. The fuel/ equipment types considered in a 11 locations include electric resistance, gas, and electric heat pump. $0 i 1$ is also analyzed in Albany, New York, and Providence, Rhode Island, because it has a larger role in newly constructed 


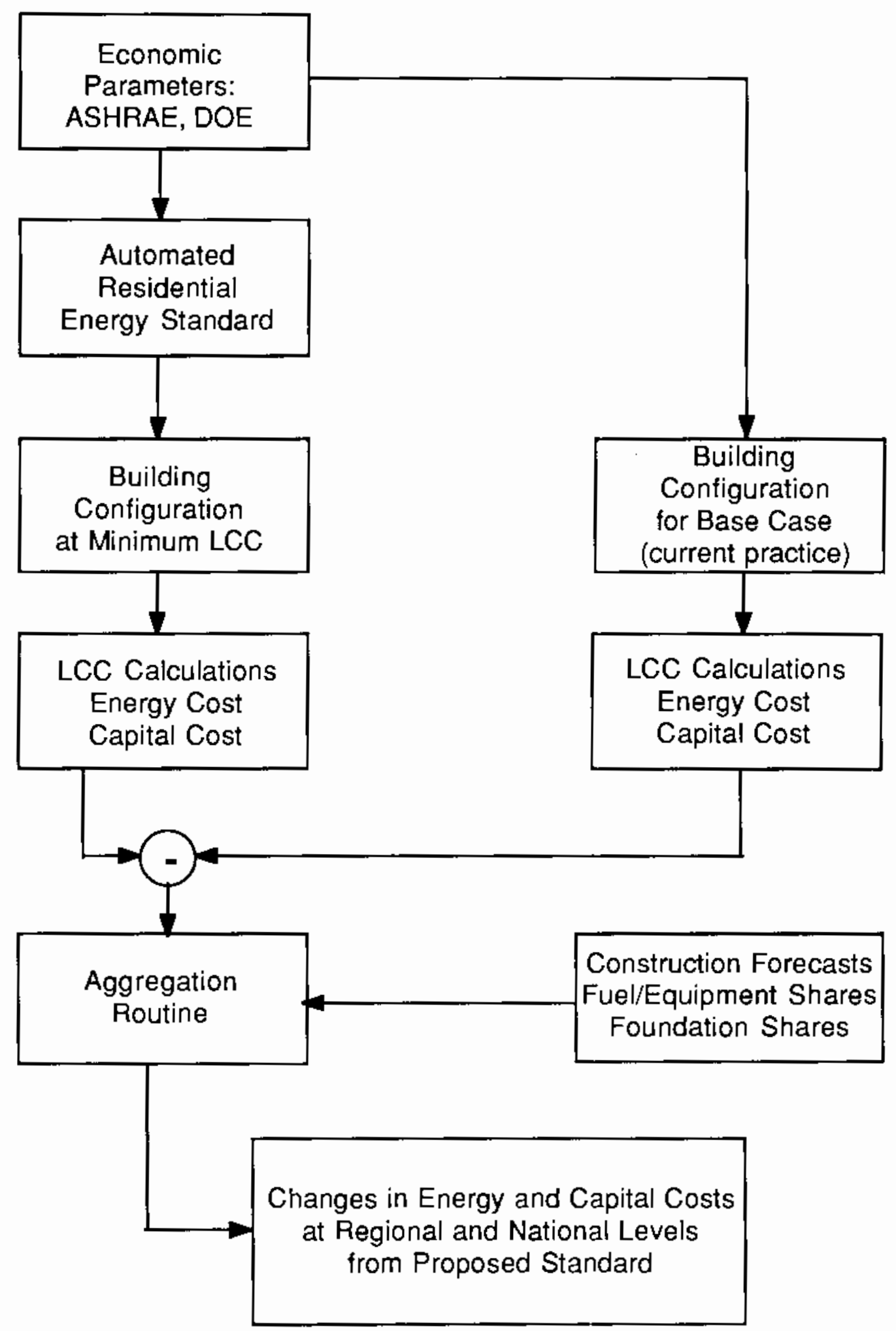

FIGURE 4.1. Overview of the Analytical Process 
housing. For manufactured housing, $L P G$ is also considered instead of heat pumps because of the prevalence of LPG use in manufactured housing.

The life-cycle cost of the ARES-generated building configuration is calculated from a societal perspective, as is that of the same building constructed according to current practice (determined by a survey of state code building requirements). This difference in 1 ife-cycle costs for capital and energy for each location, building type, and foundation type, represents the additional cost which the standard imposes. It is this difference in cost that is aggregated to regional and national totals, based on housing construction trends and their regional shifts, fuel/equipment preferences, and foundation types.

Once the direct impact of these changes in life-cycle cost has been aggregated to a national total, the indirect effects can be assessed. The method for assessing the indirect economic and employment impacts of the standard relies on the 1977 Input/0utput (I/0) model of the U.S. economy. The difference between capital costs that would be incurred in the construction of the ARES-configured building and those of the buildings constructed according to current practice is introduced as changes in final demands for the I/0 model to simulate the effect of the direct costs of the standard on the U.S. economy. Likewise, the difference in energy costs, allocated to the different fuels, is introduced as changes in final demand and the $1 / 0$ model is again simulated to measure the effect of the energy savings due to the proposed standard. These changes are represented as increments or decrements in the output of all industry. The industry output, in turn, is factored by the labor-intensity of the corresponding industry to yield the change in employment that would result from the standard.

\subsection{BUILDING CONFIGURATION USING ARES}

The set of economic assumptions presented in Table 4.1 are introduced into the ARES software to determine the configuration of buildings in each of twelve locations. The twelve locations are presented in Table 4.2. The software relies upon a data base that contains site-specific information such as construction costs and weather data. With this site-specific information, 
IABLE 4.1. Economic Parameters Used in the Economic Analysis

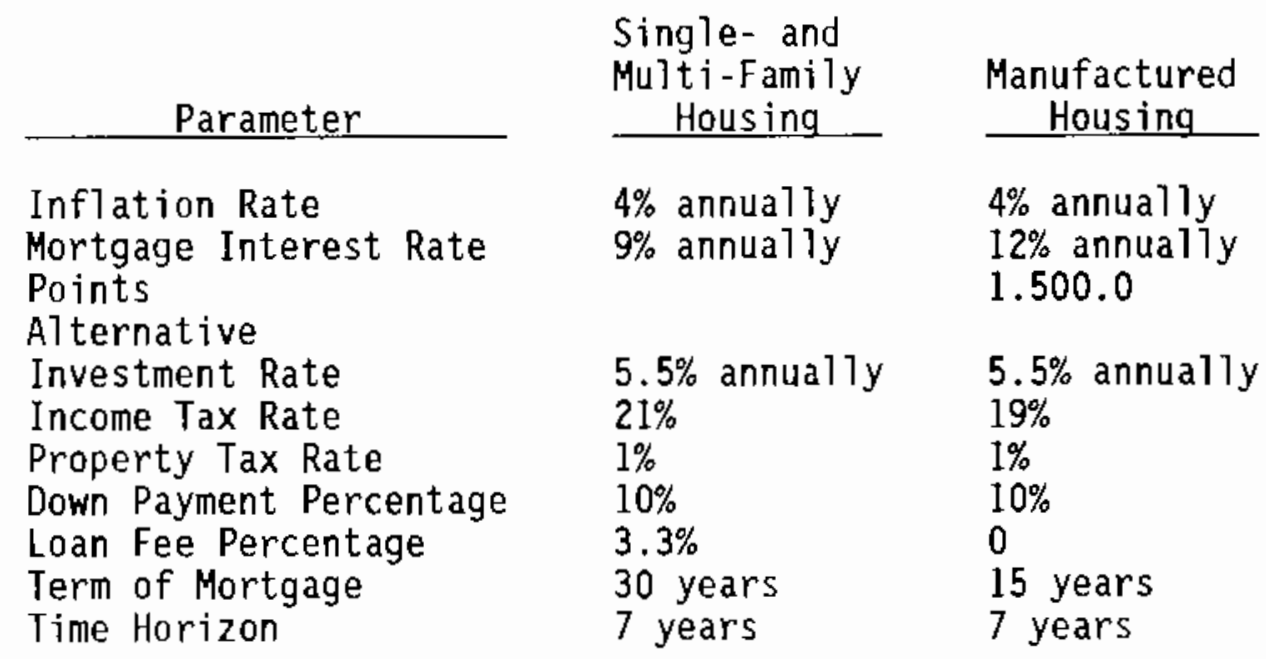

IABLE 4.2. Locations and Census Regions

Census Region

Northeast

South

North Central

West
Location

Albany, New York

Providence, Rhode Isiand

Tampa, Florida

Atlanta, Georgia

Fort Worth, Texas

Minneapolis, Minnesota

Phoenix, Arizona

Los Angeles, California

Pasadena, California

Santa Ana, California

Denver, Colorado

Seattle, Washington

ARES finds the combination of energy conservation measures that will minimize the consumer's life-cycle cost of providing energy for the residence.

The life-cycle costs of complying with the standard take into account the special circumstances of the typical consumer. Most people buying a house, for example, take out a mortgage, so that the major portion of the costs of the energy conservation measures is amortized over the life of the loan. On average, homeowners occupy a specific dwelling for only seven 
years. ARES' minimum life-cycle calculations, therefore, use a time horizon of only seven years and discount the initial costs as the mortgage is paid off. So the initial costs, from the consumers' perspective, include the down-payment and associated closing costs. The interest on the mortgage is tax deductible to the homeowner, so this is taken into account as well.

The life-cycle costs in ARES are evaluated from the perspective of the consumer, but these life-cycle costs are not suitable for society's perspective. Accordingly, the components of the building, as configured by ARES for the consumer's perspective, are used as a basis for calculating the lifecycle costs from society's perspective.

\subsection{CALCULATION OF LIFE-CYCLE COSTS}

The relevant 1 ife-cycle costs include three components: the initial cost of capital improvements, operation and maintenance costs, and fuel costs. By calculating the discounted present value of each of these components over an appropriate time horizon, the costs of the standard can be assessed.

The costs to the consumer will differ from society's costs for two major reasons: 1) the tax benefits that accrue to the homeowner; and 2) the amortizing of initial costs as the mortgage is paid off. From society's view, homeowner tax benefits are simply a transfer--either from non-homeowners to homeowners or, if the cost is financed by a deficit, through intergenerational transfers. The amortizing of initial costs, as done in the algorithm used in ARES, assumes that the consumer purchases the house with a down-payment and a loan. The costs of the energy conservation measure are incurred with each loan payment, and these are discounted costs. From society's point of view, the home and the energy conservation measure purchase arrangement is a transfer--a financial one; the cost to society is not reflected in the discounted mortgage payment, but rather in the resource use that occurs when the house is constructed. For these two major reasons the life-cycle costs are different for the homeowner and for society.

The effect of taking society's perspective rather than the consumers' is to increase the costs of the standard relative to the energy savings, but 
to augment the energy savings, albeit discounted, as the time horizon is extended. Since the resource use occurs when the house is built, the initial cost does not get discounted as it would if it were spread out over an amortization period. Society incurs the cost of the energy conservation measure at the time of installation; the costs are not discounted for socjety as they are for the consumer; therefore, the costs are higher for society. For the evaluation of the energy savings, from society's perspec. tive, the appropriate time frame is not the average time that an individual resides in the home, but rather the economic 7 ife of the building. For this analysis, this time period was chosen to be 15 years. To avoid the necessity of predicting equipment replacement costs, the time period was not extended beyond this.

\subsection{AGGREGATION OF DIRECT IMPACTS}

The determination of direct impacts requires aggregation of the perhousing unit life-cycle costs to regional and national totals. The twelve sites used to represent the four Census regions are shown in Table 4.2. The difference between the life-cycle costs under the proposed standard and those under current practice are calculated for twelve locations for each building type, fuel/equipment type, and foundation type. The aggregation routine uses these incremental costs at each of these sites as prototypical of the difference in life-cycle costs for that region, so that the effects of the standard can be inferred using forecasted construction trends by region.

State-level housing construction forecasts were used to reflect anticipated shifts in construction growth trends within each region ("City's Share"), and to allocate residential housing construction between fuel/equipment preferences ("Fuel Type") and foundation types ("Foundation"). Each of these factors is used to calculate a weight to allocate the incremental perunit housing costs appropriately, as foliows:

\section{WEIGHT $=$ CITY'S SHARE * FOUNDATION * FUEL TYPE}

This weight is then multiplied by the regional housing construction forecasts and the incremental 1 ife-cycle costs to calculate the total effect for the 
units in each location for each foundation type and fuel type. In addition, cooling costs are then multiplied by the share of new housing with airconditioning in order to reflect the penetration of air-conditioning in the region. The effect for each location is then aggregated to regional and national totals.

Tables $4.3,4.4$, and 4.5 present the factors used to calculate the weights for single-family, multi-family and manufactured homes, respectively. For example, from the Albany row of Table 4.3, a single-family home built with gas heat on a slab foundation would have a weight equal to 0.05456 $(=0.62 * 0.44 * 0.2)$; i.e., the incremental 1 ife-cycle costs and the discounted present value of energy savings constitute about 5.5 percent of the total costs and savings for single-family housing in the Northeast region. This 5.5 percent is then multiplied by the incremental capital costs and energy savings to provide an estimate of the net benefit (cost) for a single-family house in Aibany. This product is then multiplied by the forecast housing starts for single-family housing in the Northeast region. When Albany and Providence are added together, a single-family housing estimate for the Northeast is obtained. This aggregation process was performed for each building type and aggregated to regional and national totals. (Section 4.7 offers detailed descriptions of the data and its sources for these factors.)

\subsection{CALCULATION OF TOTAL IMPACTS}

The direct impacts, obtained from the aggregation routine, are used to calculate the total (direct + indirect) impacts of adopting the standard. This calculation relies on the 1977 input-output structure of the U.S. economy as reported by the U.S. Department of Commerce (see Section 4.7 for data sources). The construction costs of imposing the standard were introduced into the vector of final demands and the output by industry was caiculated. Similarly the energy savings implied by the aggregation routine were introduced into the vector of industry final demands via the bridge matrix by first estimating the final demand changes that resuit from an additional dollar of sales of one of the three fuels sold to consumers. This calculation relies on the familiar input-output identity: 
IABLE 4.3. Regional Factors Used in Aggregation Process, Single-Family Housing Census/City Share Electricity Gas HP Oil $\begin{aligned} & \text { City's Slab Crawlspace Basement Basement } \\ & \text { Shol }\end{aligned}$

$\begin{array}{lllllllllll}\text { Northeast } & & & & & & & & & & \\ \text { Albany } & 0.62 & 0.15 & 0.44 & 0.16 & 0.25 & 0.20 & 0.09 & 0.39 & 0.26 & 0.43 \\ \text { Providence } & 0.38 & 0.15 & 0.44 & 0.16 & 0.25 & 0.20 & 0.09 & 0.39 & 0.26 & 0.43\end{array}$

\begin{tabular}{|c|c|c|c|c|c|c|c|c|c|c|}
\hline South & & & & & & & & & & \\
\hline$\overline{T a m p a}$ & 0.30 & 0.21 & 0.31 & $0.4 B$ & - & 0.64 & 0.20 & 0.14 & 0.02 & 0.91 \\
\hline Atlanta & 0.30 & 0.21 & 0.31 & 0.48 & - & 0.64 & 0.20 & 0.14 & 0.02 & 0.91 \\
\hline Ft. Worth & 0.30 & 0.21 & 0.31 & 0.48 & - & 0.64 & 0.20 & 0.14 & 0.02 & \\
\hline
\end{tabular}

$\vec{\infty}$

\section{North Central}

Minneapolis 1.00

$\begin{array}{llll}1.00 & 0.08 \quad 0.82 \quad 0.10 & -\end{array}$

$0.12 \quad 0.12$

0.41

0.35

0.62

West

Phoenix

0.15

0.12

$\begin{array}{llll}0.6 B & 0.20 \quad-\quad 0.61\end{array}$

0.20

0.17

0.02

0.70

Los Angeles

0.19

0.12

$0.680 .20-0.61$

0.20

0.17

0.02

0.60

Santa Ana

0.19

0.12

$0.680 .20-0.61$

0.20

0.17

0.02

0.60

Pasadena

0.19

0.12

$\begin{array}{llll}0.68 & 0.20 \quad-0.61\end{array}$

0.20

0.17

0.02

0.60

Denver

0.14

0.12

$\begin{array}{llll}0.68 & 0.20 & - & 0.61\end{array}$

0.20

0.17

0.02

0.24

Seattle

0.12

0.12

$0.680 .20-0.61$

0.20

0.17

0.02

0.24 
IABLE 4.4. Regional Factors Used in Aggregation Process, Multi-Family Housing

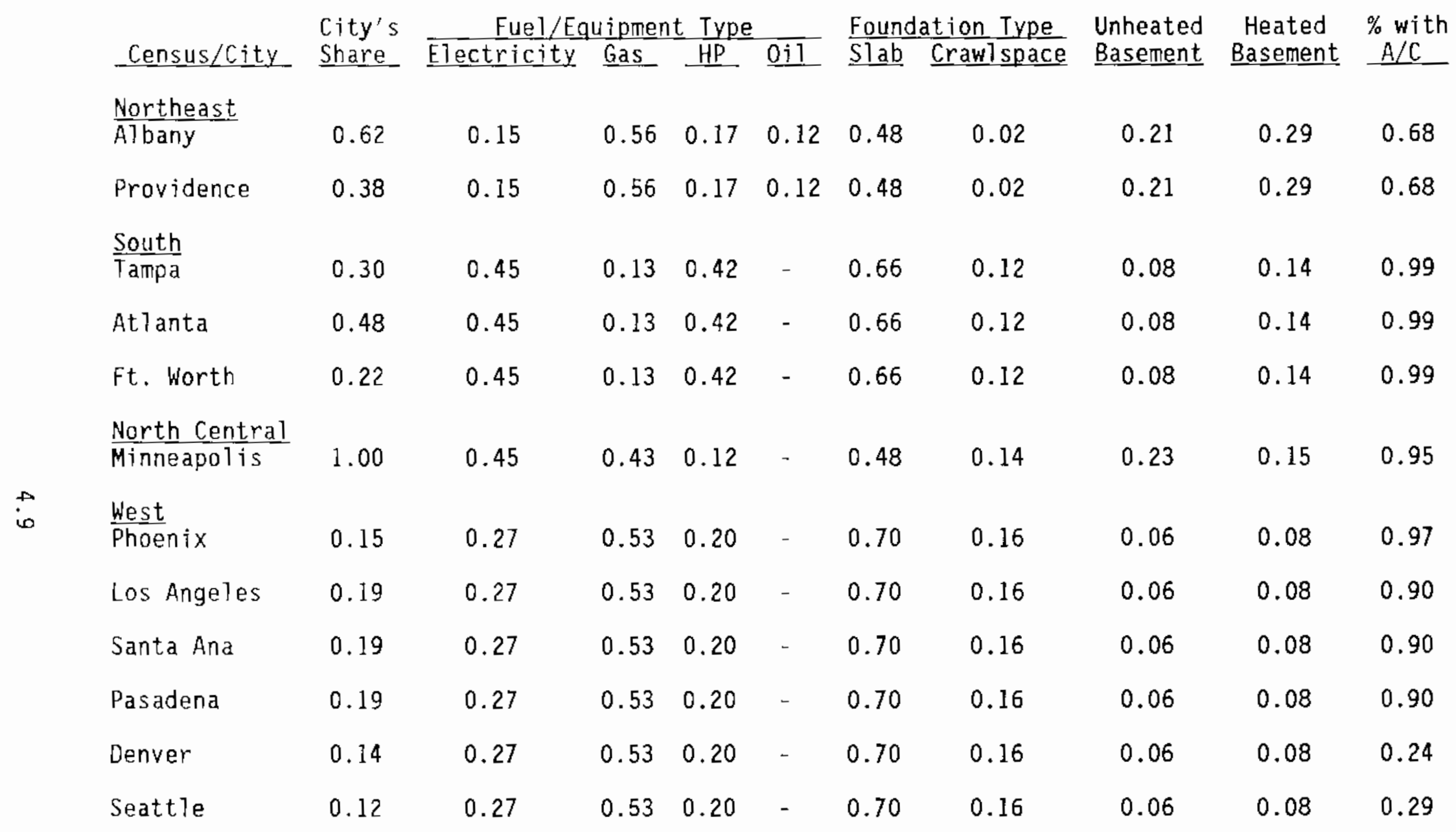


IABLE 4.5. Regional Factors Used in Aggregation Process, Manufactured Housing

\begin{tabular}{|c|c|c|c|c|c|c|c|c|c|c|}
\hline Census/City & $\begin{array}{l}\text { City's } \\
\text { Share }\end{array}$ & $\frac{\text { Fuel/Eo }}{\text { Electricity }}$ & $\underline{\text { uipmer }}$ & $\frac{t \text { Typs }}{L P G}$ & $\overline{0 i I}$ & $\begin{array}{l}\text { Found } \\
\text { Slab }\end{array}$ & $\frac{\text { tion Type }}{\text { Craw? space }}$ & $\begin{array}{l}\text { Unheated } \\
\text { Basement }\end{array}$ & $\begin{array}{c}\text { Heated } \\
\text { Basement }\end{array}$ & $\begin{array}{l}\% \text { with } \\
\text { A/C }\end{array}$ \\
\hline$\frac{\text { Northeast }}{\text { Albany }}$ & 0.62 & 0.04 & 0.23 & 0.07 & 0.66 & - & 1.00 & - & - & 0.36 \\
\hline Providence & 0.38 & 0.04 & 0.23 & 0.07 & 0.66 & - & 1.00 & . & - & 0.36 \\
\hline$\frac{\text { South }}{\text { Tampa }}$ & 0.30 & 0.34 & 0.31 & 0.35 & - & - & 1.00 & - & - & 0.78 \\
\hline At7anta & 0.48 & 0.34 & 0.31 & 0.35 & - & - & 1.00 & - & - & 0.78 \\
\hline Ft. Worth & 0.22 & 0.34 & 0.31 & 0.35 & - & - & 1.00 & - & - & 0.78 \\
\hline$\frac{\text { North Central }}{\text { Minneapol is }}$ & 1.00 & 0.13 & 0.55 & 0.32 & - & - & 1.00 & - & - & 0.62 \\
\hline$\frac{\text { West }}{\text { Phoenix }}$ & 0.15 & 0.26 & 0.57 & 0.17 & - & - & 1.00 & - & - & 0.49 \\
\hline Los Angetes & 0.19 & 0.26 & 0.57 & 0.17 & - & - & 1.00 & - & - & 0.49 \\
\hline Santa Ana & 0.19 & 0.26 & 0.57 & 0.17 & - & - & 1.00 & - & - & 0.49 \\
\hline Pasadena & 0.19 & 0.26 & 0.57 & 0.17 & - & - & 1.00 & - & - & 0.49 \\
\hline Denver & 0.14 & 0.26 & 0.57 & 0.17 & - & - & 1.00 & - & - & 0.49 \\
\hline Seattie & 0.12 & 0.26 & 0.57 & 0.17 & - & - & 1.00 & - & - & 0.49 \\
\hline
\end{tabular}




$$
X=(I-A)^{-1} F
$$

where $X=$ Output by industry

$A=$ Input-output matrix

$F=$ Final demands by industry

$I$ = Identity matrix.

To estimate the construction impacts, the fraction of manufactured homes was first calculated (11.5 percent), then a $\$ 100$ million dollar addition to final demand was distributed between manufactured and stick-built homes. This $\$ 100$ million final demand vector was then premultiplied by the Leontief inverse, $(I-A)^{-1}$, to calculate the vector of industry outputs. This increase in construction brought about an increase in gross output of $\$ 197$ million, with about $\$ 90$ million in the housing construction industry and more than $\$ 11$ million in manufactured housing.

The bridge matrix that al7ocates consumer expenditures to industry demand indicates that increases in consumer expenditures on electricity and natural gas increase the respective utitities, while an increase in fuel 017 consumption increases the industry final demands of the petroleum refining industry primarily, but with slight additions to iumber and products, chemicals, and utilities. The evidence concerning the current housing stock suggests that about 30 percent of total fuel use is electricity, 55 percent is natural gas and the remaining 15 percent is fuel $0 i 1$ and propane. These allocations were distributed to industries according to the bridge matrix and normalized to $\$ 100$ million. Then this final demand vector was premultiplied by the Leontief inverse to determine the industry output associated with changes in the use of fuels within residential homes. The results of this calculation indicate that $\$ 100$ million of energy saved would reduce industry output by $\$ 212$ million, with the bulk of that reduction accruing to the utility sectors that market the gas and electricity.

Employment impacts were determined by calculating the labor intensity (hours of empioyment per dollar of output) by industry corresponding to the vector $X$, then multiplying the estimated output for construction and fuel changes by these intensities. These changes in hours of work were then 
adjusted to reflect 1986 employment and hours, then translated into jobs by dividing the hours by 2080 , the total number of hours in a 52-week, regularshift year. The $\$ 100$ million change in construction causes a change in employment of about 2760 jobs, while a $\$ 100 \mathrm{million}$ change in fuel use brings about a change of 1950 jobs.

\subsection{SENSITIVITY ANALYSIS}

The ARES buildings configurations and the resulting 1 ife-cycle cost computations rely on the set of economic parameters presented in Table 4.1 . The sensitivity of these results was tested over a range of the critical economic parameters in order to assess the validity of the conclusions. The economic parameters that were tested include fuel prices, the alternative investment rate, and the time horizon. The homeowners' life-cycle cost was also analyzed as part of the sensitivity analysis.

Only changes in fuel price were tested for every location and fuel/ equipment type and aggregated to regional and national total. The large number of variable economic parameters limited the amount of sensitivity analysis performed for every prototype Tocation and fuel/equipment type. However, by analyzing the difference between fuel costs (reported in Section 3.1.3) and cost changes that result from varying other parameters at specific sites, one can estimate the magnitude of change at the national level for other parameters. For the remaining parameters tested, several locations and fuel/equipment types were selected and the per-unit changes were then compared to the per-housing unit changes that occurred when changing the fuel price.

\subsection{DATA}

This section presents the data sources for the factors used in the aggregation routine. Each of the twelve locations are weighted according to the share of the region's construction growth that it will receive. Based on National Association of Home Builders' forecasts of single- and multi-fami'y housing starts and their distribution across the states, the region's hous ng 
forecasts are allocated to the locations used in this analysis. (a) Manufactured housing forecasts were calculated to be twelve percent of private housing starts (as experienced between 1981-1986), from Industrial Outiook 1988.

The foundation type data for single-family housing came from the U.S. Census report entit]ed Characteristics of New Housing 1985. Over the 19831985 period, the average percentage of new housing with a foundation of "S1ab," "Crawlspace," or "Full or Partial Basement" was calculated for each of the four Census regions. The "full or partial basement" category was further broken down into heated and unheated basement categories. The Energy Information Administration publication entitled Housing Characteristics 1984 provided the data about heated and unheated basements (in current stock). The foundation type data for multi-family housing came from an Oak Ridge National Laboratory publication (Christian 1987) that contains state-level data regarding the share of multi-family basements that are insulated and uninsulated. For manufactured housing, crawlspace was considered the foundation type in all cases.

The fuel/equipment type was factored in using data from The Residential and Commercial Buildings Data Book (Amols et al. 1988), compiled from Bureau of the Census' "Characteristics of New Housing, Construction Reports." The data cite the shares of electricity, gas, and oil for homes constructed in 1986 for single- and multi-family housing. By using data presented for equipment usage, the portion of electrical equipment that is heat pumps was also calculated. All totals were controlled in order to account for the small percentage of "other" fuels in each region.

Data revealing the amount of single- and multi-family housing that is air-conditioned also came from The Residential and Commercial Data Book. The single-family percentage represents the percentage of housing constructed in 1986 that has central air-conditioning. The multi-family housing data represent the percentage of housing bui]t in 1986 that has air-conditioning

(a) Personal Communication, 8/12/87, Bob Vitianeuva, National Association of Homebuilders. 
the share of housing with air-conditioning was adjusted on a locationby-location basis so that the locations have more realistic air-conditioning penetration rates; however, the West region's control total of 50 percent penetration was retained. For manufactured housing, the data present the share of current housing with air-conditioning by census region.

The input-output structure of the U.S. economy, used as the basis for determining the total impact of the standard, is described in the May 1984 Survey of Current Business, "The Input-Output Structure of the U.S. Economy, 1977" (DOC 1984). The Survey is a publication of the Bureau of Economic Analysis, U.S. Department of Commerce. The actual table used was the detailed, 537 industry/commodity table, aggregated to 130 sectors. These 130 sectors are, except for the detailed energy commodities, similar to the aggregation used by the U.S. Department of Energy's Energy Disaggregated Input-Output (EDIO) table. The bridging of consumer purchases to industry output was done according to Table B, "Input-Output Commodity Composition of Personal Consumption Expenditures", reported in the DOC (1984) publication cited above. The translation to employment was done using the U.S. Department of Labor hours-by-industry data to construct a measure of the labor intensity of industry (again aggregated to the EDIO level). The hours per dollar of compensation were deflated from the 1977 value to the 1986 value based on compensation of employee divided by employment adjusted by average weekly hours worked, then translating these hour values into jobs as explained above. Compensation, employment and average weekly hours were taken from Tables B-23, B-32 and B-41 respectively of the February 1988 Economic Report of the President. 
APPENDIX A

DESCRIPTION OF HOUSING PROTOTYPES UNDER THE PROPOSED STANDARD 


\section{APPENDIX A}

\section{DESCRIPTION OF HOUSING PROTOTYPES UNDER THE PRDPOSED STANDARD}

This appendix contains a description of the housing prototypes and the other variables used in the analysis, including the considerations given to the selection of locations, fuel prices, and the economic parameters.

\section{A.1 SELECIION OF THE CASE STUOY RESIDENCES}

Over seventy case study homes were created for this analysis using the Automated Residential Energy Standard (ARES) software to determine levels of energy conservation measures that would meet the proposed voluntary standard. These case study homes cover three types of residential housing, up to five fuel/heating appliance specifications and ten locations. In addition, each site-built case study home's package of energy conservation measure included insulation requirements for four alternative foundations. Considerations used to select the residences to be studied included the following:

Building Prototypes. The ARES software produces standards for three types of residential structures: single-family site-built homes, multifamily site-built homes, and singie-wide manufactured (mobile) homes. Each type is represented as a generic, relatively simple prototype, with set dimensions and features. Each site-built prototype also comes with severa? foundation options, white the manufactured home is modeled only on the crawl space foundations. Energy conservation measure packages generated by the standard show required insulation levels for each foundation type selected for consideration by the user. Tables A.1 and A.2 Tist the building types, their dimensions, and the foundation options that were studied in this anatysis.

Case Study Locations. Twe Tve cities distributed across the continentai United States were selected as locations where VOLRES would be compared to existing energy-efficiency-related building practices and requirements. These locations represent a range of heating and cooling degree day values 
IABLE A.1. Prototype Residential Units

House Type

1) Single-Family Residence

2) Single-Family Residence

3) Single-Family Residence

4) Single-Family Residence

5) Multi-Family Residence

6) Multi-Family Residence

7) Multi-Family Residence

8) Multi-Family Residence

9) Manufactured Home
Foundation Type

Crawl Space
Unconditioned Basement
Conditioned Basement
Slab
Crawl Space
Unconditioned Basement
Conditioned Basement
Slab
Crawl Space

Unconditioned Basement

Conditioned Basement

Slab

Craw1 Space

Unconditioned Basement

Conditioned Basement

Crawl Space

TABLE A.2. Residential Housing - Selected Unit Dependent Characteristics

\section{Component}

\section{Ceiling Square Feet}

Wa11 Square Feet

Floor Square Feet

Slab Perimeter Linear Feet

Basement Wa11 Perimeter Linear Feet
Single. Multi- Manu. Family Family Home

$\begin{array}{rrr}1540 & 600 & 902 \\ 1328 & 640 & 1162 \\ 1540 & 600 & 902 \\ 166 & 40 & \text { NA } \\ 166 & 40 & \text { NA }\end{array}$

that span the predominant climate conditions in the United States. Regions where new residential construction has been, and will be particularly heavy were slightly emphasized in the selection of the locations.

Fuels. The standards generated for VOLRES by the ARES software are specific to fuels and fuel/heating appliance applications selected by the user from among the five types provided in ARES. To limit the standard variations at each location somewhat, a VOLRES standard was developed for the two predominant heating fueis in each city. (When electricity was one of those fueis, however, there actuaily were three variations of the standard created, since ARES creates separate standards for electric forced air and electric heat pump appliances.) The predominant fuel types were also used in calculating life-cycle costs of the baseline residences. The two primary heating fuels were selected using data from The Residential and Commercial Buildings Databook (Amols et ai. 1988) that showed the distribution hy heating fuels of recently constructed new homes. In two locations (Albany 
and Providence), oil was considered as well as electricity and natural gas, because of its widespread use as a heating source.

\section{A.2 SIMULATION OF ENERGY CONSERVATION MEASURE LEVELS IN THE CASE STUDY RESIDENCES}

Generation of the energy conservation measure package with the ARES software requires the user to make a number of chojces that tailor the standard to local conditions, prices and construction trends. The choices that were used to develop the proposed standard case study homes are listed below.

\section{A.2.1 Fue] Prices}

Prices used for selected fuels were current (1986) location-specific per unit prices obtained from published sources. The primary source of natural gas prices for each study location was the Annua? Househeating Survey published by the American Gas Association (AGA 1986). Electricity prices were obtained from The Electrical World Directory of Electric Utilities, 1985-1986 (McGraw-Hil1 1985). Fuel oil and LPG prices were obtained from the State Energy Price and Expenditure Report, 1985, published by the Energy Information Administration (DOE 1987). Sensitivity of ARES output to variations in fuel price was studied extensively. Table A.3 presents the fuel prices used in the economic analysis.

\section{IABLE A.3. Fuel Prices}

\begin{tabular}{|c|c|c|c|c|}
\hline & $\begin{array}{c}\text { (\$ per MMBtu) } \\
\text { Electricity }\end{array}$ & Gas & $\angle P G$ & $\underline{0 i 1}$ \\
\hline $\begin{array}{l}\text { Tampa, Florida } \\
\text { Phoenix, Arizona } \\
\text { Atlanta, Georgia } \\
\text { Seattle, Washington } \\
\text { Denver, Colorado } \\
\text { Minneapolis, Minnesota } \\
\text { Fort Worth, Texas } \\
\text { Pasadena, California } \\
\text { Santa Ana, California } \\
\text { Los Angeles, California } \\
\text { Albany, New York } \\
\text { Providence, Rhode Is land }\end{array}$ & $\begin{array}{l}22.45 \\
25.65 \\
19.11 \\
12.40 \\
20.52 \\
18.17 \\
20.75 \\
22.10 \\
22.10 \\
22.10 \\
20.08 \\
28.20\end{array}$ & $\begin{array}{l}6.07 \\
5.71 \\
5.42 \\
5.47 \\
4.26 \\
5.27 \\
5.10 \\
6.00 \\
6.00 \\
6.00 \\
7.64 \\
7.28\end{array}$ & $\begin{array}{r}10.70 \\
10.25 \\
9.22 \\
8.46 \\
6.55 \\
7.79 \\
8.53 \\
8.66 \\
8.66 \\
8.66 \\
11.12 \\
11.43\end{array}$ & $\begin{array}{l}-- \\
-- \\
-- \\
-- \\
-- \\
-- \\
-- \\
-- \\
-- \\
-- \\
8.07 \\
7.76\end{array}$ \\
\hline
\end{tabular}




\section{A.2.2 Construction Costs}

ARES contains resident data bases with average energy conservation measure construction costs (1986 dollars) for eleven regions covering the continental United States. These costs are default values that can be modified by individual users of the software. For the purpose of this study, no changes were made to the default values, which were set by the ASHRAE technical evaluation committee.

\section{A.2.3 Heating Appl iance Efficiencies}

ARES optimizes both envelop energy conservation measure features and space conditioning appliance efficiencies to minimize building life-cycle energy costs. Appliance efficiency values in ARES are not allowed to drop below the minimum efficiencies mandated in the National Appliance Energy Conservation Act (NAECA) of 1987 (42 USC 6201). However, the software can select higher efficiencies, if the life-cycle cost of the home can be lowered by doing so. NAECA minimum efficiencies become mandatory between 1990 and 1992 (the date varies by type of appliance) for new space conditioning equipment. These minimums were also used to develop the comparative life-cycle costs and energy use of the baseline (current code) prototypes.

\section{A.2.4 Windows}

Users of VOLRES can set the amount (window-to-floor-area ratio) and percent facing south (except in manufactured housing) of fenestration in the prototypes. Users can also limit the types of glazing that are to be considered in creating the standard. Modifying any of these items can result in changes to other energy conservation measure requirements. The case study (proposed standard and baseline) prototypes used the following parameters: 1) window area was set at 12 percent of floor area; 2) one-fourth of the window area was placed on the south-facing wall; and 3) ARES was not allowec to consider single pane/thermal break, triple pane/no thermal break, and reflective low $E$ (low E-sun) glazing options for the windows. While those types of glazing are commercially available, they are not yet widely market:d 
for residential construction and are seldom used by builders (although low E-reflective glazing is becoming more popular in sunbelt states). ${ }^{\text {(a) }}$

\section{A.2.5 Economic Parameters}

ARES contains a file listing the economic parameters that guide its life-cycle cost calculations for energy conservation measures. In conjunction with other files and programming, the software generates the package of energy conservation measure components that represents minimized building life-cycle cost in any location. The user can edit the initial (default) values assigned to these economic parameters. A slightly different standard often results from such changes. For the purposes of this assessment, the default values for the economic parameters were used in single- and multifamily housing. The economic parameters used for the analysis of manufactured housing were changed in some cases to more accurately reflect manufactured home buyers' environment.

(a) Telephone conversation between Todd Taylor, PNL, and Steve Selkowitz, Lawrence Berkeley Laboratory, March 15, 1988. 

APPENDIX B

DETAILED DATA AND SAMPLE ARES RUNS 


\section{APPENDIX B}

\section{DETAILED DATA AND SAMPLE ARES RUNS}

This appendix contains detailed data used in the aggregation process of the economic analysis for all building types and all locations. Data included are housing forecasts, fuel shares, foundation type shares, the cities' share of regional growth, and the penetration of air-conditioning. Sample output runs from ARES are also included in this appendix. 


\section{Weights Used in Aggreqation Process}

\begin{tabular}{|c|c|c|c|c|c|c|c|c|c|c|c|c|c|}
\hline & $N$ & & & & & & & & & & & & \\
\hline & & LRARY-EE & & & & LOANY-GE & & & & BANY-HF & IPG & & \\
\hline PEGIONAL FD & JRECAST5 & $1000^{\prime} 51$ & $\{d\}$ & & & & & & & & & & \\
\hline SF $(a)$ & -1788 & 196 & 176 & 196 & 176 & 196 & $19 t$ & 176 & 196 & $17 t$ & $17 t$ & $17 t$ & 176 \\
\hline & 1939 & 212 & 212 & 213 & 212 & 212 & 212 & 312 & 212 & 212 & 212 & 212 & $5 ! 2$ \\
\hline & 1970 & 229 & 229 & 229 & 227 & $22 ?$ & 227 & 229 & อ2ท & 229 & 229 & 227 & E? \\
\hline & 1991 & $2 P B$ & 223 & 228 & 223 & 223 & 228 & 223 & 228 & 223 & $22 \mathrm{~B}$ & 223 & 278 \\
\hline & 1992 & $22 t$ & 826 & 226 & 226 & 226 & $22 \hbar$ & 226 & 226 & 226 & 226 & 226 & 234 \\
\hline & 199.3 & 150 & 160 & 150 & 160 & 160 & $1 \leq 0$ & 160 & 150 & 160 & 160 & 150 & $1: 50$ \\
\hline & 1994 & 148 & 142 & 148 & 148 & 248 & 143 & 148 & 148 & 149 & 149 & 148 & $\ln$ \\
\hline & 1995 & 139 & 139 & 139 & 139 & 139 & 139 & 139 & 139 & 139 & 139 & 137 & 139 \\
\hline 179 & $t-2000$ & 770 & 770 & 770 & 770 & 770 & 770 & 770 & 770 & 770 & 770 & 770 & 770 \\
\hline 200 & $1-2005$ & 1265 & 64.5 & 665 & 665 & $6+5$ & 665 & 605 & S65 & $6 \dot{5}$ & $6 \times 5$ & $6 a^{5}$ & 6.5 \\
\hline CITY'S SIAQ & & $0 . d \hat{E}$ & 0.62 & 0.62 & 0.62 & 0.62 & 062 & $0 . t, 2$ & 062 & $0.6 Z$ & 0.62 & 0.62 & 0.42 \\
\hline TFFFU TOATT & CN TYPE & 0.20 & 0.09 & 0.39 & 0.32 & 0.20 & 0.09 & 0.39 & 0.32 & 0.20 & 0.09 & 0.39 & 0.12 \\
\hline 5F-FUFL TYD & & 0.15 & 0.15 & 0.15 & 0.15 & 0.44 & 0.44 & 0.44 & 0.44 & $0.1 \epsilon$ & 016 & 0.16 & 0.1 .6 \\
\hline $5 F-y w[T H A$ & & 0.43 & 0.43 & 0.43 & 0.4 .3 & 0.43 & 0.43 & 0.43 & 0.49 & 0.43 & 0.43 & 0.49 & 0.73 \\
\hline Ho $(h)$ & -1780 & 61 & 61 & 61 & 61 & $\iota 1$ & 61 & 61 & 61 & 61 & 61 & 61 & 41 \\
\hline & 1939 & 54 & 54 & 54 & 54 & 54 & 54 & 54 & 54 & 54 & 54 & 54 & :4 \\
\hline & 1990 & 61 & 61 & $6 i$ & 61 & 61 & 61 & 61 & 61 & 61 & 61 & 61 & $\vdots 1$ \\
\hline & 1971 & 63 & 63 & 63 & 63 & 69 & 69 & 63 & 63 & 63 & 63 & 4.3 & : 3 \\
\hline & 1992 & 6.3 & 69 & 63 & 63 & 6.7 & 6.7 & 69 & 63 & {$[3$} & 63 & 69 & $: 3$ \\
\hline & 1990 & 42 & 42 & 4 & 49 & 42 & 42 & 42 & 42 & 42 & 42 & 42 & .2 \\
\hline & 1994 & $3 t$ & $\partial t$ & 36 & 26 & 36 & 36 & 36 & $3 \dot{n}$ & 36 & 3í & 36 & $\therefore t$ \\
\hline & 1995 & 33 & 33 & 33 & 39 & 3.3 & 33 & 33 & 33 & 30 & 39 & 33 & : 39 \\
\hline 179 & 62000 & 170 & 190 & 190 & 190 & 190 & 170 & 170 & 190 & 170 & 190 & 190 & $1: 0$ \\
\hline 200 & $11-2005$ & 125 & 125 & 125 & 1.25 & 125 & 125 & $1 E s$ & 15.5 & 125 & 125 & 1.25 & li: \\
\hline CITY'S SHAE & & 0.62 & 0.62 & 0.63 & $0 . t \hat{E}$ & 0.62 & 0.62 & $0 . t 2$ & $0.6 \hat{\varepsilon}$ & $0.6 \vec{\imath}$ & 0.62 & 0.62 & 0.2 \\
\hline H-F-FUNDAT I & CON TYPC & 043 & 0.02 & 0.21 & 029 & 049 & 0.02 & 021 & 0.29 & 0.43 & 0.02 & 0.21 & $0: 7$ \\
\hline MF-FLEL TYP & & 0.15 & 0.15 & 015 & 0.15 & 0.56 & 0.56 & 0.56 & $0.5 i$ & 0.17 & 017 & 0.17 & 0.7 \\
\hline$M F-W W I T-1 A$ & & $0.5 B$ & 0.68 & 0.65 & 0.58 & 0.63 & 0.63 & 0.48 & 0.53 & 0.3 .9 & 0.68 & $0.6 \mathrm{G}$ & 0.13 \\
\hline $\mathrm{MHICl}$ & $-17 \mathrm{Re}$ & 35 & 35 & 35 & 35 & 35 & $\exists$ & 3.5 & 35 & 35 & 35 & 35 & $\therefore 5$ \\
\hline & 1939 & 36 & 36 & Э6 & 36 & $3 t_{3}$ & 36 & $3 \dot{q}$ & 36 & 96 & 36 & 36 & S' \\
\hline & $19 \%$ & 40 & 40 & 40 & 40 & 40 & 40 & 40 & 40 & $4 C_{3}$ & 40 & 40 & .0 \\
\hline & 1791 & 40 & 40 & 40 & 40 & 40 & 40 & 40 & 40 & 40 & 40 & 40 & (') \\
\hline & 1792 & 37 & 97 & 39 & 39 & 39 & $3 ?$ & 39 & 39 & 39 & 39 & 39 & $: 9$ \\
\hline & 1993 & 23 & 23 & 23 & 28 & $2 B$ & 23 & 23 & 39 & 20 & 23 & 29 & E⿰氵工丁 \\
\hline & 1994 & 25 & 25 & 25 & 25 & 25 & 25 & 25 & 25 & 25 & 25 & 25 & $6 j$ \\
\hline & 1995 & 23 & 23 & 29 & 23 & 23 & 23 & 23 & 23 & $\sqrt{3}$ & 23 & 23 & 63 \\
\hline 199 & $5-2000$ & 131 & 131 & 131 & 13. & 131 & 131 & $1 \div 1$ & 131 & $13 !$ & 131 & $: 31$ & $1: 1$ \\
\hline 200 & $1-2005$ & 100 & 100 & 103 & 103 & 100 & 100 & 163 & 103 & 100 & 108 & 109 & 103 \\
\hline CITY'S SHAR & & 0.62 & 0.62 & 0.62 & 0.42 & 0.62 & $0.6 \hat{c}$ & 062 & 0.62 & 0.62 & $0 . t 2$ & 062 & $0, t^{2}$ \\
\hline WHTFDARATI & ON TYPE & 0.00 & 1.00 & 0.00 & 0.00 & 0.00 & 1.00 & 0.00 & 0.00 & 0.00 & 1.00 & 0.00 & 0.0 .2 \\
\hline$H+F \backslash E L$ TYP & & 0.04 & 0.04 & 004 & 0.04 & 023 & 0.23 & 0.23 & 0.23 & 0.07 & 007 & 0.07 & 0.67 \\
\hline MH-I WTTHA & & $0.3 i$ & 036 & 0.36 & 0.36 & 0.36 & 0.36 & 0.36 & 0.36 & 0.36 & 0.36 & 0.36 & 0.35 \\
\hline
\end{tabular}




\section{Weights Used in Aggregation Process (contd)}

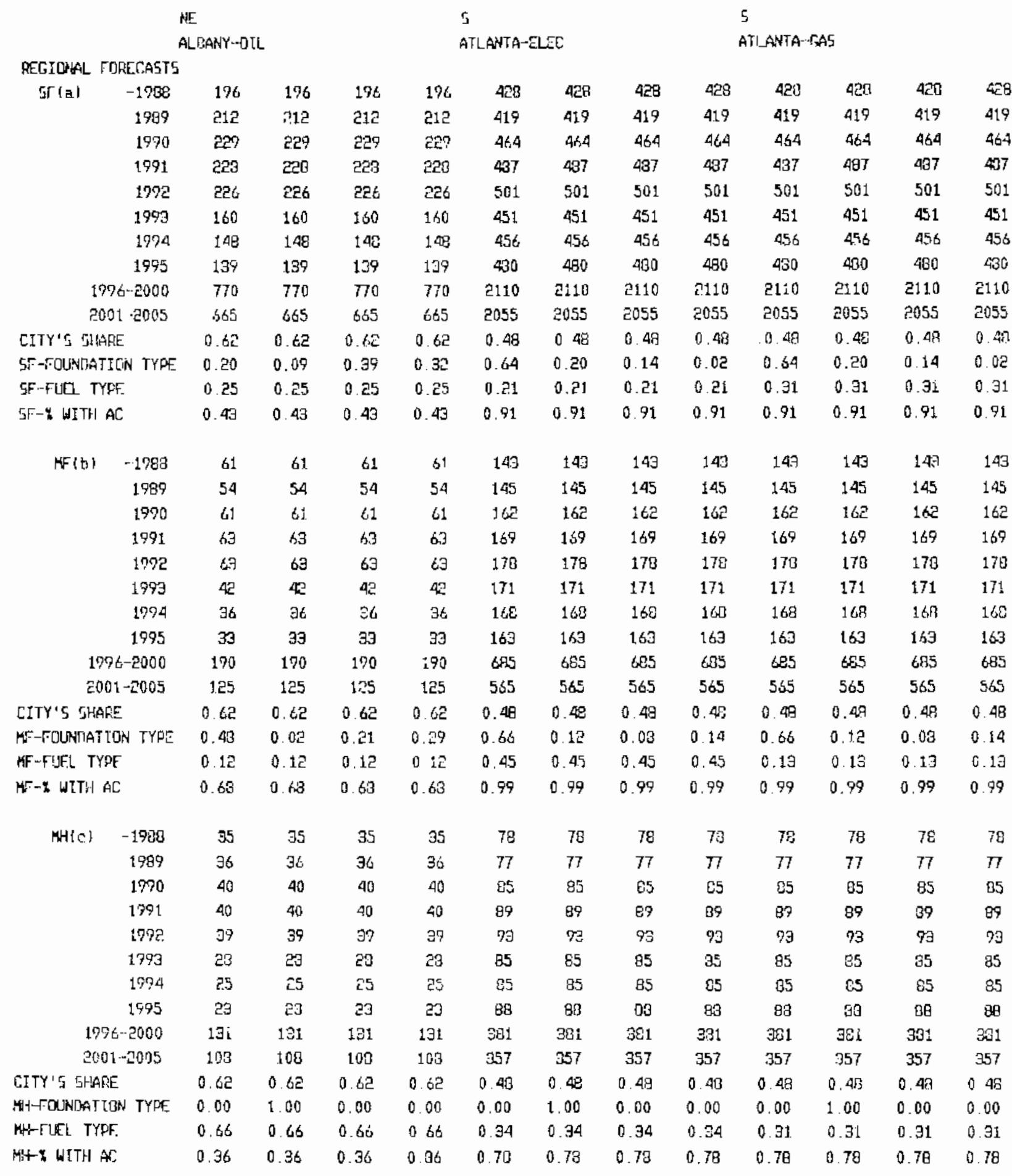




\section{Weights Used in Aggregation Process (contd)}

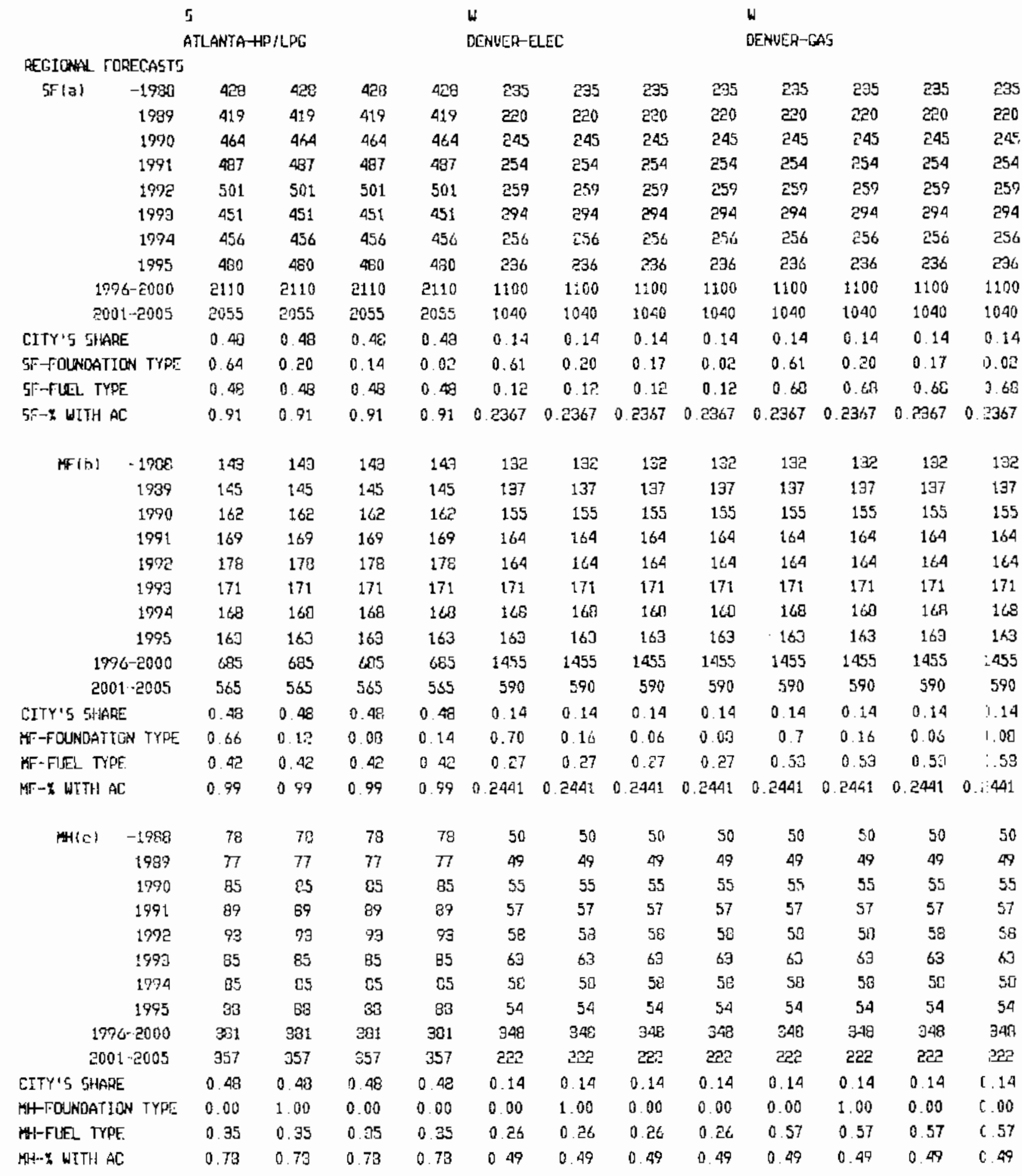


Weights Used in Aggregation Process (contd)

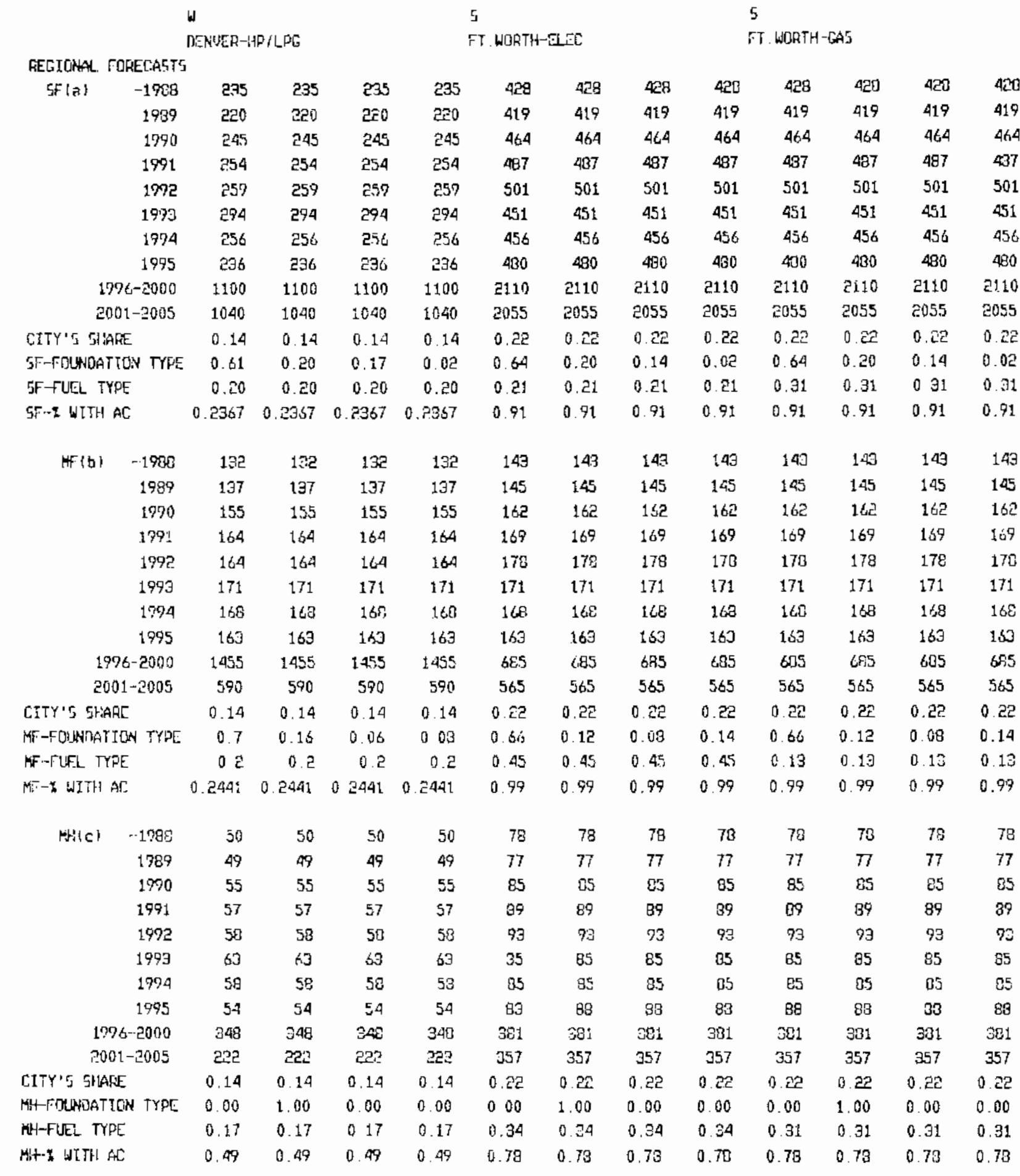




\section{Weights Used in Aggregation Process (contd)}

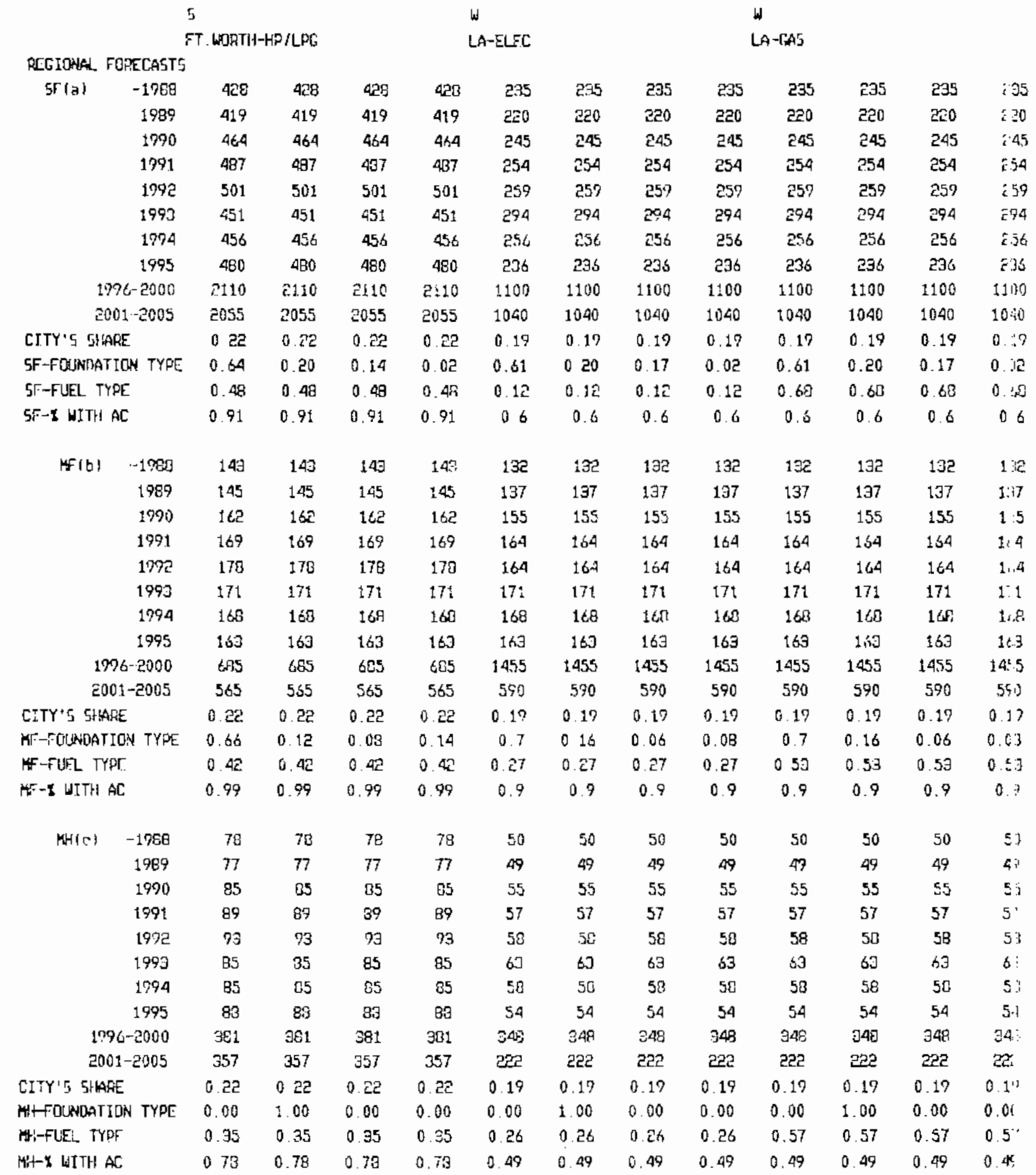




\section{Weights Used in Aggregation Process (contd)}

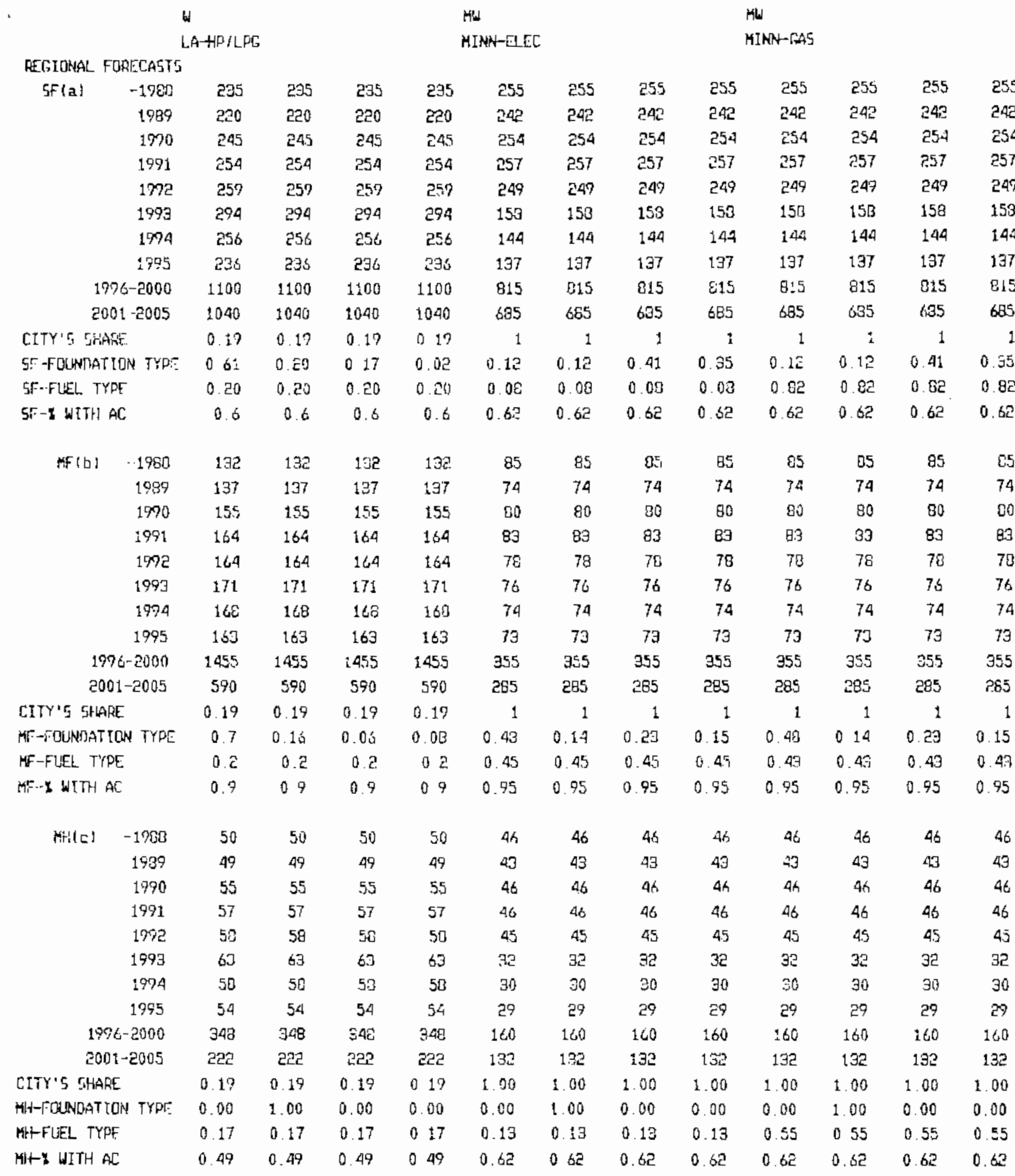




\section{Weights Used in Aggregation Process (contd)}

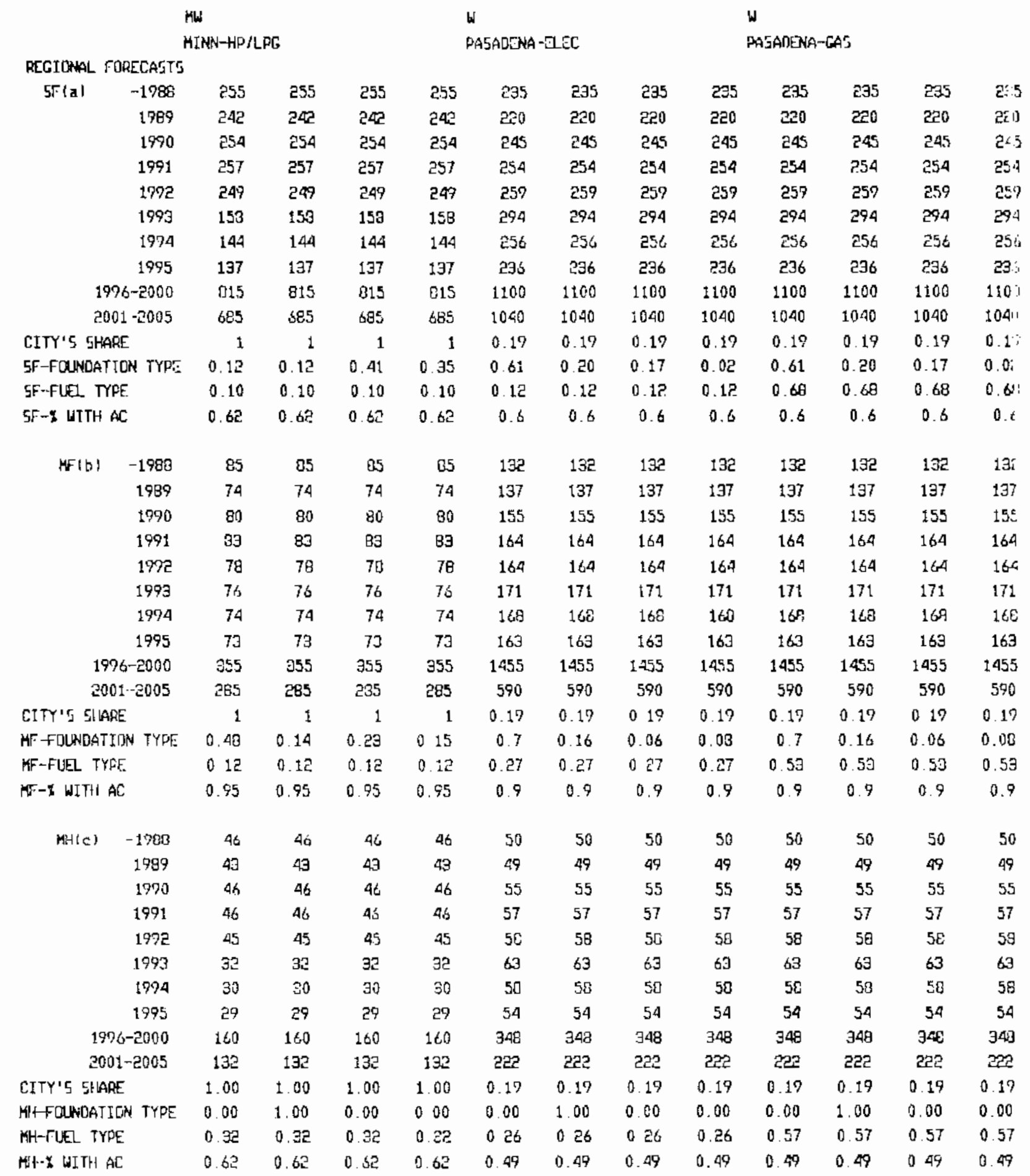




\section{Weights Used in Aggregation Process (contd)}

\begin{tabular}{|c|c|c|c|c|c|c|c|c|c|c|c|c|c|}
\hline & W & ASADENA & IP/LPG & & & HOENIX- & & & & HEEMIX- & & & \\
\hline REGIONAL $T$ & WECASTS & & & & & & & & & & & & \\
\hline $5 F(a)$ & -1908 & 235 & 235 & 235 & 235 & 235 & 235 & 295 & 235 & 235 & 295 & 235 & 235 \\
\hline & 1939 & 220 & 220 & 220 & 220 & 320 & 220 & 220 & 220 & 220 & 220 & 220 & 220 \\
\hline & 1990 & 245 & 245 & 245 & 245 & 245 & 245 & 245 & 245 & 245 & 245 & 245 & 245 \\
\hline & 1991 & 254 & 254 & 254 & 254 & 254 & 254 & 254 & 254 & 254 & 254 & 254 & 254 \\
\hline & 1992 & 259 & 259 & 259 & 259 & 259 & $25 ?$ & 259 & 259 & 259 & 259 & 259 & $25 \%$ \\
\hline & 1993 & 294 & 294 & 294 & 294 & 294 & 294 & 294 & 294 & 294 & 294 & 294 & 294 \\
\hline & 1994 & 256 & 256 & 256 & 256 & 256 & 256 & 256 & 256 & es. & 256 & 256 & 256 \\
\hline & 1995 & 236 & 295 & 236 & 236 & 236 & 236 & 236 & 236 & 236 & 236 & 236 & 236 \\
\hline & $96-2000$ & $\$ 100$ & 1100 & 2100 & 1100 & 1100 & 1160 & 1100 & 1100 & 1100 & 1200 & 1100 & 1100 \\
\hline & $1-2005$ & 1040 & 1040 & 1040 & 1040 & 1040 & 1040 & 1040 & 1040 & 1040 & 1040 & 1040 & 1040 \\
\hline EITY's $51 \mathrm{~K}$ & & 0.17 & 0.19 & 0.19 & 0.19 & 0.15 & 0.15 & 0.15 & 0.15 & 0.15 & 0.15 & 0.15 & 0.15 \\
\hline SF-FOUNDAT & CON TYPT: & 0.61 & 0.20 & 0.17 & 0.02 & 0.51 & 0.20 & 0.17 & 0.03 & 0.51 & 0.20 & 0.17 & 0.02 \\
\hline 5F-FUEL TY & & 0.20 & 0.20 & 0.20 & 0.20 & 0.12 & 0.12 & 0.12 & 0.12 & 0.68 & 0.68 & 0.60 & 0.68 \\
\hline GF-I WITH & & 0.6 & 0.6 & 0.6 & 0.5 & 0.7 & 0.7 & 0.7 & 0.7 & 0.7 & 0.7 & 0.7 & 0.7 \\
\hline $\mathrm{MF}(\mathrm{b})$ & -1988 & 132 & 192 & 192 & 132 & 132 & 192 & 172 & $10 P$ & 132 & 192 & 132 & 132 \\
\hline & 1989 & 137 & 137 & 1.97 & 137 & 197 & 197 & 137 & 137 & 137 & 137 & 197 & 197 \\
\hline & 199i) & 155 & 155 & 155 & 155 & 155 & 155 & 155 & 155 & 155 & 155 & 155 & 155 \\
\hline & 1991 & 164 & 164 & 164 & 164 & 164 & 164 & 164 & 164 & 164 & 164 & 164 & 164 \\
\hline & 1972 & 164 & 164 & 164 & 164 & 164 & 164 & 164 & 164 & 164 & 164 & 164 & 164 \\
\hline & 1993 & 171 & 171 & 171 & 171 & 171 & 171 & 171 & 171 & 171 & 171 & 171 & 171 \\
\hline & 1994 & 168 & 168 & $16 \theta$ & 160 & 168 & 162 & 168 & 168 & $16 \%$ & 168 & 168 & 168 \\
\hline & 1995 & 163 & 169 & 163 & 163 & 163 & 163 & 163 & 163 & 163 & 163 & 163 & 163 \\
\hline & $c-2000$ & 1455 & 1455 & 1455 & 1455 & 1455 & 1455 & 1455 & 1455 & 1455 & 1455 & 1455 & 1455 \\
\hline & $11-2005$ & 590 & 590 & 550 & 590 & 590 & 590 & 590 & 590 & 590 & 590 & 590 & 590 \\
\hline CITY'S SHA & & 0.17 & 0.19 & 0.17 & 0.19 & 0.15 & 015 & 0.15 & 0.15 & 015 & 0.15 & 0.15 & 0.15 \\
\hline MF-FOUNDAT & LON TYPE & 0.7 & 0.15 & 0.06 & 0.08 & 0.7 & 0.16 & 0.06 & 0.03 & 0.7 & 0.16 & 0.06 & 0.03 \\
\hline KF $-F \cup J F L$ TY & & 0.2 & 0.2 & 0.2 & 0.2 & 0.27 & 0.27 & 0.27 & 0.27 & 0.52 & 0.53 & 0.53 & 0.53 \\
\hline$M^{T}-\Phi W^{\prime}[T H$ & & 0.9 & 0.9 & 0.9 & 0.9 & 1.0 & 10 & 1.0 & 1.0 & 1.0 & 1.0 & 1.0 & 1.0 \\
\hline $\mathrm{BH}(E)$ & $-1 \% 38$ & 50 & so & 50 & 50 & 50 & 50 & 50 & 50 & 50 & 50 & 50 & 50 \\
\hline & 1989 & 49 & 49 & 49 & 49 & 49 & 49 & 49 & 49 & 49 & 49 & 49 & 49 \\
\hline & 1990 & 55 & 55 & 55 & 55 & 55 & 55 & 55 & 55 & 55 & 55 & 55 & 55 \\
\hline & 1991 & 57 & 57 & 57 & 57 & 57 & 57 & 57 & 57 & 57 & 57 & 57 & 57 \\
\hline & 1792 & 50 & $5 \varepsilon$ & 50 & 58 & $5 \varepsilon$ & 58 & 58 & 50 & 50 & 58 & 50 & 58 \\
\hline & 1993 & 63 & 63 & $\dot{0}$ & 63 & 63 & 69 & 63 & 69 & 69 & 63 & 69 & 63 \\
\hline & 1974 & 58 & 58 & 50 & 50 & 58 & 58 & 53 & 58 & 50 & 58 & 50 & 50 \\
\hline & 1995 & 54 & 54 & 54 & 54 & 54 & 54 & 54 & 54 & 54 & 54 & 54 & 54 \\
\hline & $26,-2000$ & 348 & 348 & כ48 & 348 & 348 & 348 & $3 \rightarrow 8$ & 348 & 348 & $3 A B$ & 340 & 348 \\
\hline & $11-2005$ & 222 & 222 & 222 & 232 & 222 & $22 \pi$ & 222 & ฉ22 & 222 & 2222 & 292 & 222 \\
\hline CITY'5 SHLA & & 0.19 & 019 & 0.19 & 0.19 & 0.15 & 0.15 & 0.15 & 0.15 & 0.15 & 0.15 & 0.15 & 0.15 \\
\hline RitFOLNDAT & ON TYPE & 0.00 & 100 & 0.00 & 0.00 & 0.00 & 1.00 & 0.00 & 0.00 & 0.00 & 1.00 & 0.00 & 0.00 \\
\hline WHtFULL TY! & & 0.17 & 0.17 & 0.17 & 0.17 & 0.26 & 0.26 & 0.26 & 0.25 & 0.57 & 0.57 & 0.57 & 0.57 \\
\hline KHA- & & 0.49 & 0.49 & 0.49 & 0.49 & 0.49 & 0.49 & 0.49 & 0.49 & 0.49 & 0.49 & 0.49 & 0.49 \\
\hline
\end{tabular}


Weights Used in Aggregation Process (contd)

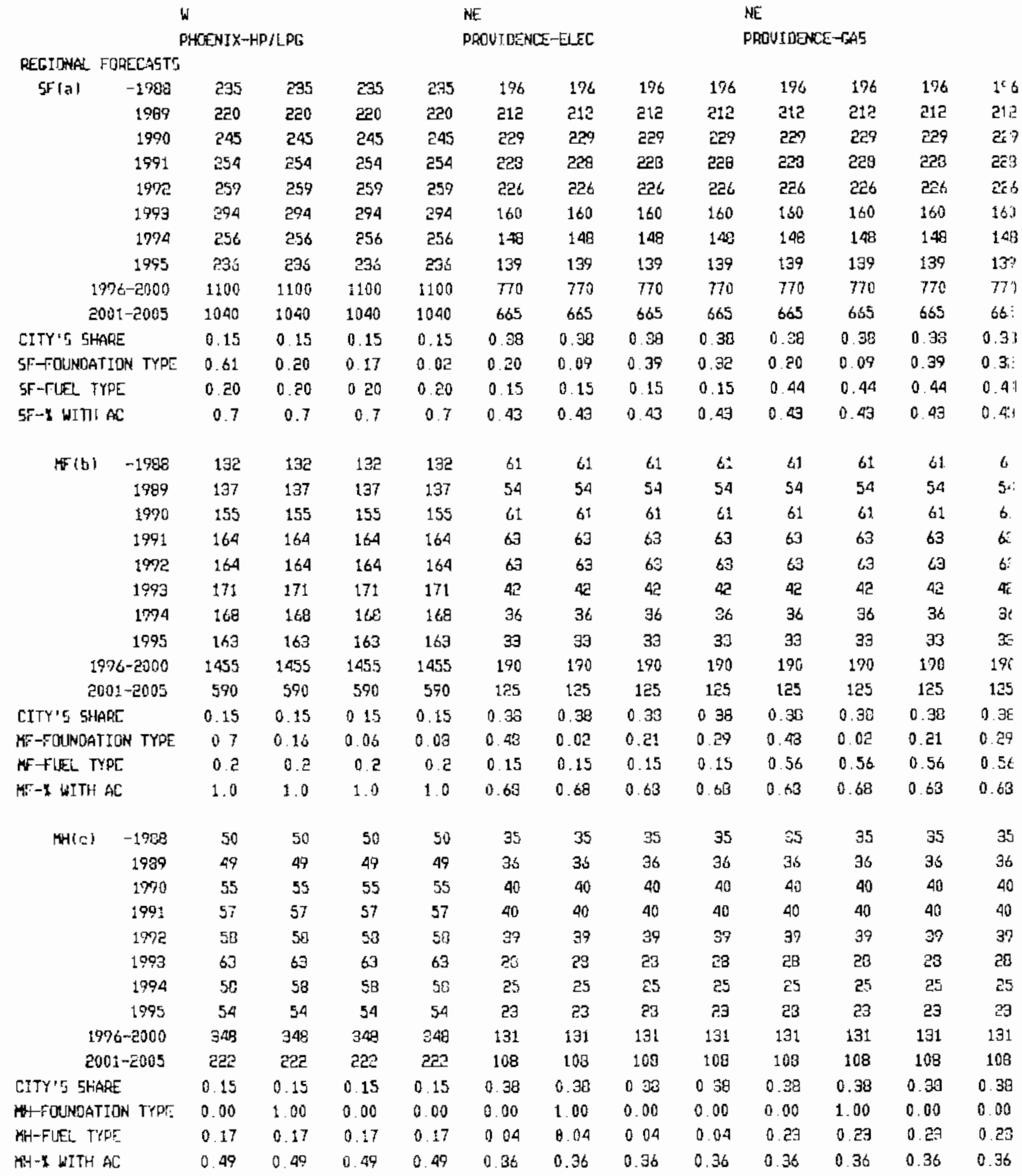




\section{Weights Used in Aqgregation Process (contd)}

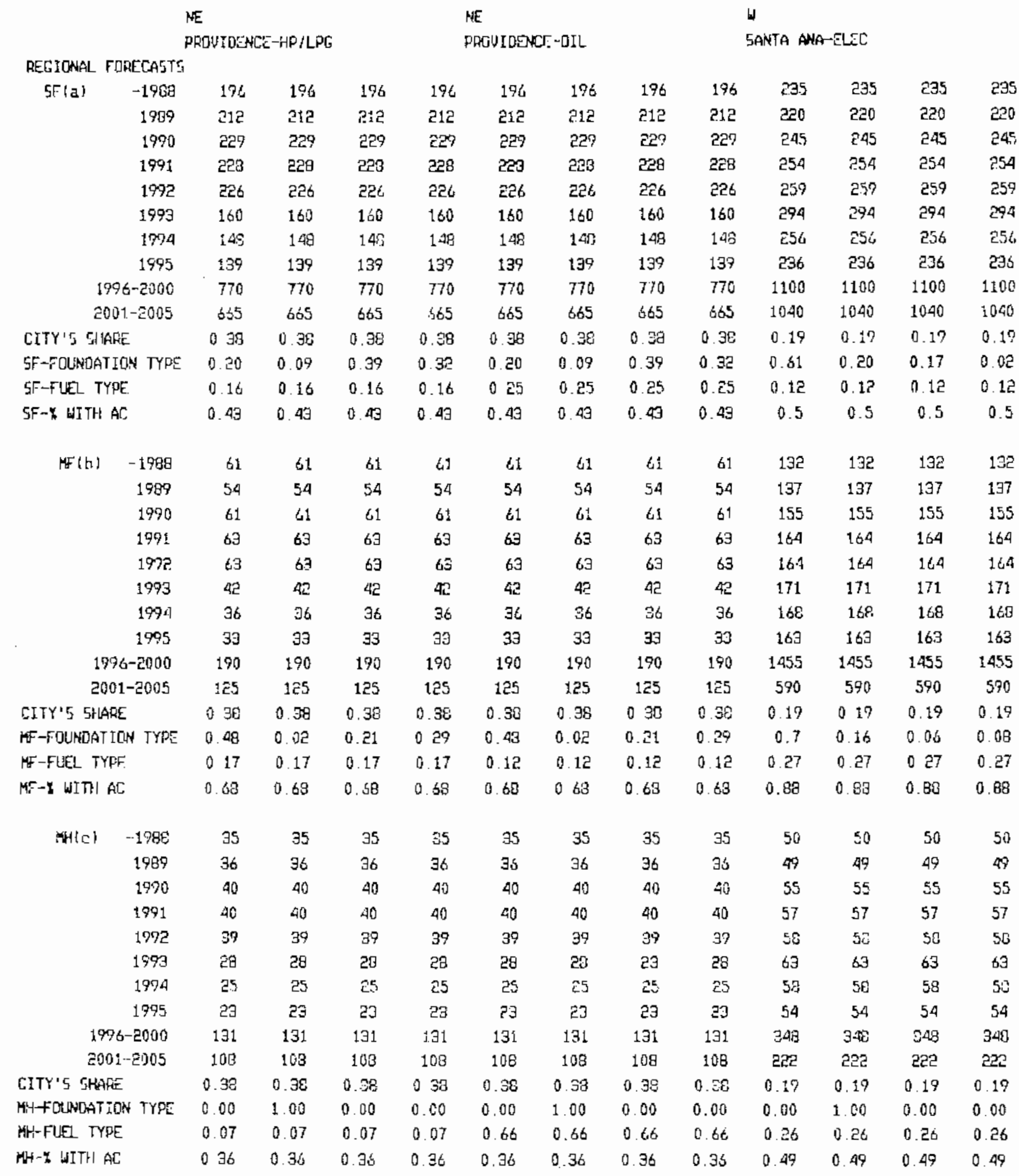




\section{Weights Used in Aggregation Process (contd)}

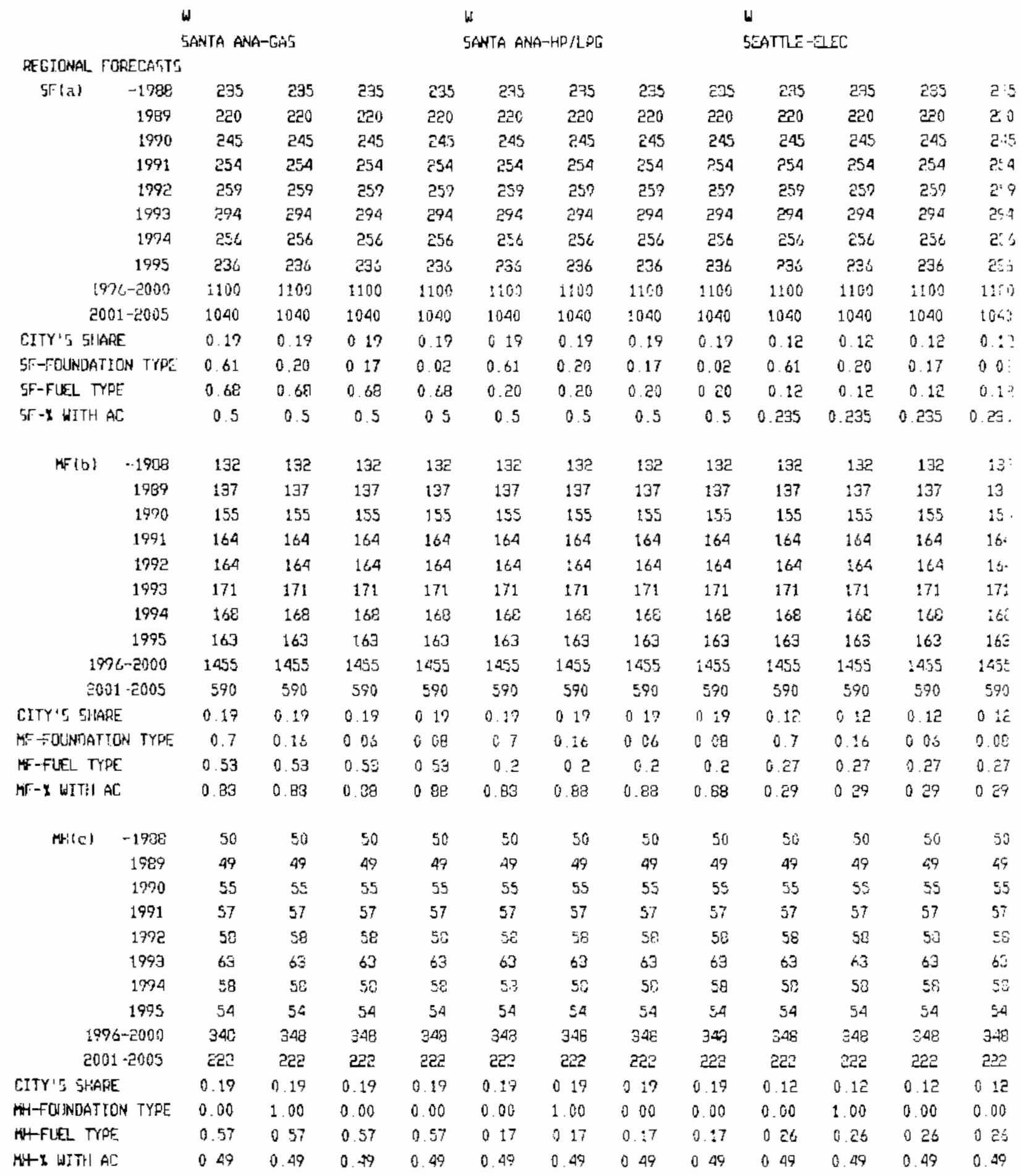




\section{Weights Used in Aggregation Process (contd)}

W

SEATTLE-GAS
W

REGIONAL FORECASTS

\begin{tabular}{|c|c|c|c|c|c|c|c|c|c|c|c|c|c|}
\hline \multirow[t]{8}{*}{ SF (a) } & -1988 & 235 & 235 & 235 & 295 & 235 & 235 & 235 & 235 & 429 & 429 & 420 & 428 \\
\hline & 1939 & $2 \Sigma 0$ & 220 & 220 & 220 & 220 & 220 & 220 & 220 & 419 & 419 & 419 & $4: 9$ \\
\hline & 1990 & 245 & 245 & 245 & 245 & 245 & 245 & 245 & 245 & 464 & 464 & 464 & 464 \\
\hline & 1991 & 259 & 254 & 254 & 254 & 254 & 254 & 254 & 254 & 497 & 497 & 497 & 37 \\
\hline & 1972 & 259 & 259 & 259 & 259 & 250 & 259 & 259 & 259 & 501 & sol & 501 & 501 \\
\hline & 1993 & 294 & 294 & 294 & 294 & 294 & 294 & 294 & 294 & 451 & 451 & 451 & 51 \\
\hline & 1994 & 256 & 256 & 256 & 256 & 256 & 256 & 256 & 256 & 456 & 456 & 456 & \\
\hline & 1995 & 235 & 296 & 236 & 236 & 226 & 236 & 236 & 236 & 480 & 480 & 480 & 480 \\
\hline \multicolumn{2}{|c|}{$19 \% 6-2000$} & 1100 & 1100 & 1100 & $\$ 100$ & 1100 & 1100 & 1100 & 1100 & 2110 & 2110 & 2110 & 110 \\
\hline \multicolumn{2}{|c|}{$2001-2005$} & 1040 & 1040 & 1040 & 1040 & 1040 & 1040 & 1040 & 1040 & 2055 & 2055 & 2055 & 2055 \\
\hline \multicolumn{2}{|c|}{ CITY'S S.HARE } & 0.12 & 0.12 & 0.12 & 0.12 & 0.12 & 0.12 & 0.12 & 0.12 & 0.3 & 0.3 & 0.3 & 0.3 \\
\hline \multicolumn{2}{|c|}{ SF-FQLADATION TYPE } & 0.61 & 0.20 & 0.17 & 0.02 & 0.61 & 0.20 & 0.17 & 0.02 & 0.61 & 0.20 & 0.17 & 0.02 \\
\hline \multicolumn{2}{|c|}{ 5F-FUEL_ TYPE } & 0.68 & 0.68 & 0.68 & 0.68 & 0.20 & 0.20 & 0.20 & 0.20 & 0.21 & 0.21 & 0.21 & 0.21 \\
\hline \multicolumn{2}{|c|}{$5 F-x$ WITH $A C$} & 0.235 & 0.235 & 0.235 & 0.235 & 0.235 & 0.235 & 0.235 & 0.235 & 0.91 & 0.91 & 0.91 & 0.91 \\
\hline \multirow{10}{*}{$M F(b)$} & -1988 & 192 & 192 & 132 & 132 & 132 & $13 ?$ & 132 & 132 & 143 & 143 & 142 & 149 \\
\hline & 1989 & 137 & 137 & 137 & 137 & 137 & 137 & 137 & 137 & 145 & 145 & 145 & 145 \\
\hline & 1990 & 155 & 155 & 15.5 & 155 & 155 & 155 & 155 & 155 & 162 & 162 & $16 \hat{2}$ & $16 \mathrm{C}$ \\
\hline & 1991 & 164 & 164 & 164 & 164 & 164 & 164 & 164 & 164 & 169 & 169 & 169 & 169 \\
\hline & 1992 & 154 & 164 & 164 & 164 & 164 & 164 & 164 & 164 & 176 & 178 & 178 & 178 \\
\hline & 1993 & $17 t$ & 171 & 171 & 171 & 171 & 171 & 171 & 171 & 171 & 171 & 171 & $17 t$ \\
\hline & 1994 & 169 & 168 & $16 \theta$ & 168 & 160 & 168 & 168 & $1 \in \theta$ & 168 & 168 & 168 & 168 \\
\hline & 1995 & 169 & 169 & 163 & 169 & 163 & 163 & 163 & 163 & 163 & 163 & 163 & 163 \\
\hline & $6-2000$ & 1455 & 1455 & 1455 & 1455 & 1455 & 1455 & 1455 & 145.5 & 685 & 685 & 685 & 685 \\
\hline & $1-2005$ & 590 & 590 & 590 & 590 & 590 & 590 & 590 & 590 & 565 & 565 & 565 & 565 \\
\hline \multicolumn{2}{|c|}{ CITY'S SHARE } & 0.12 & 0.12 & 0.12 & 0.12 & 0.12 & 0.12 & 0.12 & 0.12 & 0.3 & 0.3 & 0.3 & 0.3 \\
\hline \multicolumn{2}{|c|}{$\begin{array}{l}\text { WF FOUNDOTITIN TYPE } \\
\text { IFF-FIJEL TYPE }\end{array}$} & 0.7 & 0.16 & 0.06 & 0.08 & 0.7 & 0.16 & 0.06 & 0.38 & 0.66 & 0.12 & 0.08 & 0.14 \\
\hline \multirow{2}{*}{\multicolumn{2}{|c|}{$\begin{array}{l}\text { MF-FLEEL TYPE } \\
\text { ME-I WITH AC }\end{array}$}} & 0.53 & 0.53 & 0.59 & 0.53 & 0.2 & $0 . \bar{z}$ & $0 . \bar{E}$ & 0.2 & 0.45 & 0.45 & 0.45 & 0.45 \\
\hline & & 0.29 & 0.29 & 0.29 & 0.29 & 0.29 & 0.29 & 0.29 & 0.29 & 0.99 & 0.99 & 0.99 & 0.99 \\
\hline \multirow[t]{8}{*}{$\mathrm{HH}(\mathrm{C})$} & -1990 & 50 & so & 50 & 50 & 50 & 50 & 50 & 50 & 70 & $7 \theta$ & 70 & 70 \\
\hline & 1989 & 49 & 49 & 49 & 49 & 49 & 49 & 49 & 99 & 77 & 77 & 77 & 77 \\
\hline & 1990 & 55 & 55 & 55 & 5.5 & 55 & 55 & 55 & 55 & 85 & 85 & 85 & 95 \\
\hline & 1991 & 57 & 57 & 57 & 37 & 57 & 57 & 57 & 57 & 89 & B9 & 89 & 89 \\
\hline & 1992 & 58 & 58 & 58 & 58 & ธ尺 & 50 & 58 & 58 & 93 & 73 & 93 & 93 \\
\hline & 1993 & 33 & 63 & 63 & 63 & 63 & 63 & 63 & 63 & 85 & 85 & 35 & 85 \\
\hline & 1974 & 58 & 58 & 50 & 58 & $5 \varepsilon$ & $\mathrm{s} 8$ & $5 \varepsilon$ & 58 & a5 & 8.5 & $E .5$ & 65 \\
\hline & 1995 & 54 & 54 & 54 & 54 & 54 & 54 & 54 & 54 & 83 & 82 & 88 & 68 \\
\hline \multicolumn{2}{|c|}{$1996-2000$} & 346 & $\exists \triangle B$ & 346 & 348 & 348 & $\exists 48$ & $\ni 48$ & $\exists 4 \sqrt{3}$ & 391 & 301 & 331 & $\exists \in i$ \\
\hline \multirow{2}{*}{\multicolumn{2}{|c|}{$\begin{array}{ll} & 2001-2005 \\
\text { EITY'S } & \text { 5HARE }\end{array}$}} & 2223 & 222 & 222 & २22 & 222 & 222 & 222 & 292 & 957 & 357 & 357 & 357 \\
\hline & & 0.12 & 0.12 & 0.12 & 0.12 & 0.12 & 0.12 & 0.12 & 0.12 & 0.30 & 0.30 & 0.30 & 0.30 \\
\hline \multicolumn{2}{|c|}{ WH-FOUNDATIEN TYPE } & 0.00 & 1.00 & 0.00 & 0.00 & 0.00 & 1.00 & 0.00 & 0.00 & 0.00 & 1.00 & 0.00 & 0.00 \\
\hline \multirow{2}{*}{\multicolumn{2}{|c|}{$\begin{array}{l}\text { H-FUI TRE } \\
H-L \text { : WITH AC }\end{array}$}} & 0.57 & 0.57 & 057 & 0.57 & 0.17 & 0.17 & 0.17 & 0.17 & 0.34 & 0.34 & 0.34 & 0.34 \\
\hline & & 0.49 & 0.49 & 0.49 & 0.49 & 0.49 & 0.49 & 0.49 & 0.49 & 0.79 & 0.78 & 0.78 & 0.78 \\
\hline
\end{tabular}

5

TAMPA-ELEC 


\section{Weights Used in Aggregation Process (contd)}

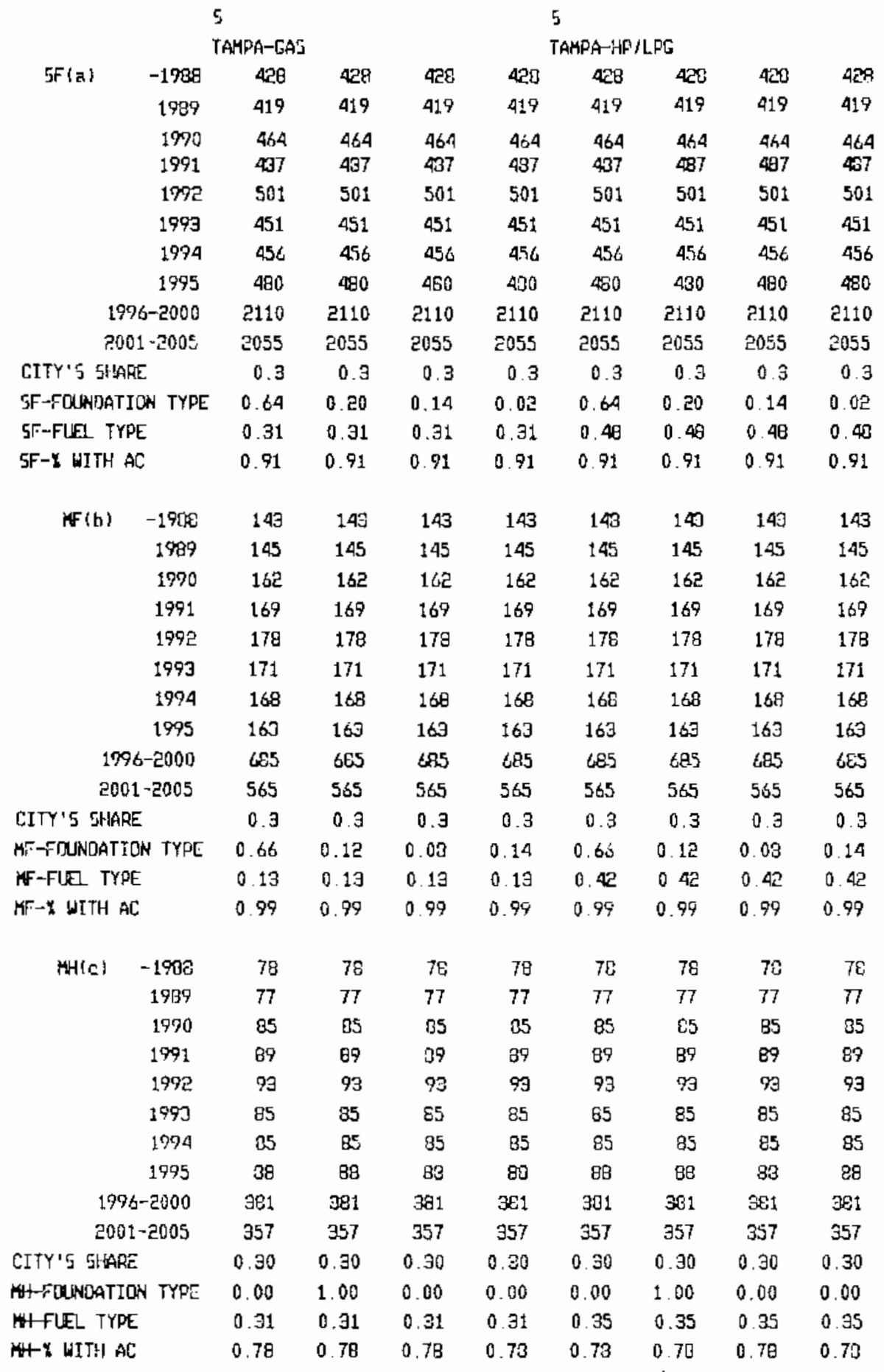

\footnotetext{
(a) Single-Fjaily

(b) Multi-Fasily

(c) Manufactured Housing

(d) Faur coluans represent foundation types: Slab,Craulspace, Unheated Basenent, Heated Basegent.
} 


\section{REFERENCES}

American Gas Association, 1986. Gas Househeating Survey: 1985. Arlington, Virginia.

Amols, G. R., K. B. Howard, A. K. Nicholls, T. D. Guerra. 1988. Residential and Commercial Buildings Data Book: Third Edition, PNL-6454, Pacific Northwest Laboratory, Richland, Washington.

Christian, J. 1987. Impact of CFC Restriction on U.S. Building Foundation Thermal Performance. ORNL/CON-245, Oak Ridge National Laboratory, Oak Ridge, Tennessee.

Department of Energy Organization Act. 1977. Pub7ic Law 95-91, August 4, 1977. 91 Stat 565, et. seq. (Section 304(a)).

Economic Report of the President. 1988. U.S. Government Printing Office, Washington, D.C.

Energy Conservation and Production Act. 1976. Public Law 94-385, August 14, 1976. 90 Stat 1144 et seq.

Energy Conservation Standards for the New Buildings Act of 1976. 42 USC 6831 et seq., as amended.

Housing and Community Development Act of 1980. Publ ic Law 96-399, October 8, 1980. (Section 326).

McGraw-Hill Publications, Co. 1985. Electrical World, Directory of Electric Utilities, 19B5-1986. New York, New York.

National Appliance Efficiency Conservation Act (NAECA). 1987. Public Law 100-12, 42 USC 6201.

National Conference of States on Building Codes and Standards (NCSBCS). 1985. Directory and Compilation of Technical and Administrative Requirements in Energy Codes for New Building Construction Used Within the United States. (Revised). Herndon, Virginia.

National Manufactured Housing Construction and Safety Standards Act. 1974. 42 USC $5403(a), 5402(7)$.

Nesse, R. J., J. W. Callaway, R. F. Darwin, A. D. Lee, S. A. Harkreader. 1988. Analys is of Alternative Manufactured Housing Energy Standards.

PNL-6496, Pacific Northwest Laboratory, Richland, Washington.

Omnibus Reconciliation Act of 1981. Public Law 97-35. 95 Stat 621

(Title 10, Subtitle D.) 
U.S. Department of Commerce (DOC), Bureau of Economic Ana7ysis. 1984. The Input-Output Structure of the U.S. Economy, 1977. Washington, D.C.

U.S. Department of Commerce (DOC) and U.S. Department of Housing and Urban Development (HUD). 1986. Characteristics of New Housing: 1985, C-25-85-13. Washington, D.C.

U.S. Department of Commerce (DOC), International Trade Administration. 1988. 1988 U.S. Industrial Outlook. Washington, D.C.

U.S. Department of Energy (DOE), Energy Information Administration, 1987. State Energy Price and Expenditure Report 1985. DOE/EIA-0376(85), Washington, D.C.

U.S. Department of Energy (DOE), Energy Information Administration. 1986. Housing Characteristics 1984. DOE/EIA-0314(84), Washington, D.C. 
PNL -6673

UC-95d

\section{DISTRIBUTION}

No. of

Copies

OFFSITE

10 DOE/Office of Scientific and Technical Information

2 J. Boulin

U.S. Dept. of Energy

Forrestal Building, CE-131

1000 Independence Ave., SW

Washington, DC 20585

J. Millhone

U.S. Dept. of Energy

Forrestal Building, CE-13

1000 Independence Ave., SW

Washington, DC 20585

J. Smith

U.S. Dept. of Energy

Forrestal Building, CE-131

1000 Independence Ave., SW

Washington, DC 20585

3 S. Walder

U.S. Dept. of Energy

Forrestal Building, CE-131

1000 Independence Ave., SW

Washington, DC 20585

T. Alereza

ADM Associates, Inc. 3299 Ramos Circle

Sacramento, CA 95827

J. Blair

DCA of Pennsylvania

Dept. of Community Affairs

Forum Building, Room 508

Harrisburg, PA 17120
No. of

Copies

OFFSITE (cont'.)

R. Busch

RD Busch and Associates

8209 Sprenger NE

Albuquerque, NM 87109

D. Conover

NCSBCS

481 Carlisle Drive

Herndon, VA 22070

R. Dixon

State of Florida

2740 Centerview Drive

Tallahassee, FL 32399

C. Gilbo

Charles F. Gilbo Consultant

201 E. Ross Street

Lancaster, PA 17602

L. Holder

LM Holder III Incorporated

50C N Cap of TX Hwy

Bldg 3

Austin, TX 78746

$Y$. Huang

Lawrence Berkeley Laboratory

One Cyclotron Road

Building 90

Berkeley, CA 94720

M. Levy

The Levy Partnership

40 East 19th Street

7 tr. Floor

New York, NY 10003 
No, of

Copies

OFFSITE (cont'.)

F. McQuiston

Ok Tahoma State University

School of Mechanical Engr.

Stillwater, OK 74078

\section{Nall}

Jones, Nall \& Davis

57 Forsyth Street NW

Suite 80

Atlanta, GA 30303

G. Raymond

Carrier Corporation

P.0. Box 4808

Syracuse, NY 13221

R. Ritschard

Lawrence Berkeley Laboratory

Building 90-3125

Berkeley, CA 94720

2 J. Rivera

D\&R International Ltd.

962 Wayne Avenue

Silver Spring, MD 20910

R. Tracey

Ryan Homes

100 Ryan Court

Pittsburgh, PA 15205

H. Trechsel

P.0. Box 211

Germantown, MD 20874-0211

J. Wright

ASHRAE

1791 Tullie Circle NE

Atlanta, GA 30329

\section{ONSITE}

DOE Richland Operations Office

R. F. Christensen, A5-90
No. of

Copies

ONSITE (cont'.)

52 Pacific Northwest Laboratory

M. R. Brambley $(10), K 5-20$

J. H. Callaway (5), K6-55

C. C. Conner, K5-20

D. B. Crawley, K5-20

C. A. Geffen, K6-55

R. E. Jarnagin, K5-20

B. M. Johnson, K5-02

L. D. Kannberg, K5-20

A. D. Lee, $K 6-55$

V. B. Lortz, K1-86

R. G. Lucas, K5-20

S. J. Marsh (3), K6-58

G. B. Parker, K5-20

R. G. Pratt, $\mathrm{k5}-20$

R. W. Reilly, K6-61

J. M. Roop (3), K6-58

T. J. Secrest, $K 5-20$

G. M. Stokes, K2-51

J. J. Tawi 1, K6-58

Z. T. Taylor (10), K5-20

J. J. Thomas, K1-86

Publishing Coordination

Technical Report Files (5), K5-20 